\title{
WestVirginiaUniversity
}

THE RESEARCH REPOSITORY @ WVU

Graduate Theses, Dissertations, and Problem Reports

2009

\section{Perceptions of ethical practices in youth livestock shows}

\author{
Sharon J. Ankrom \\ West Virginia University
}

Follow this and additional works at: https://researchrepository.wvu.edu/etd

\section{Recommended Citation}

Ankrom, Sharon J., "Perceptions of ethical practices in youth livestock shows" (2009). Graduate Theses, Dissertations, and Problem Reports. 2792.

https://researchrepository.wvu.edu/etd/2792

This Thesis is protected by copyright and/or related rights. It has been brought to you by the The Research Repository @ WVU with permission from the rights-holder(s). You are free to use this Thesis in any way that is permitted by the copyright and related rights legislation that applies to your use. For other uses you must obtain permission from the rights-holder(s) directly, unless additional rights are indicated by a Creative Commons license in the record and/ or on the work itself. This Thesis has been accepted for inclusion in WVU Graduate Theses, Dissertations, and Problem Reports collection by an authorized administrator of The Research Repository @ WVU. For more information, please contact researchrepository@mail.wvu.edu. 
Perceptions of Ethical Practices in Youth Livestock Shows

\author{
Sharon J. Ankrom
}

Thesis submitted to the

Davis College of Agriculture, Forestry, and Consumer Sciences

at West Virginia University

in partial fulfillment of requirements

for the degree of

\author{
Master of Science \\ in \\ Agricultural and Extension Education
}

Harry N. Boone, Jr., Ph.D., Chair

Deborah A. Boone, Ph.D.

Jean M. Woloshuk, Ed.D.

Division of Resource Management

Morgantown, West Virginia

2009

Keywords: agricultural education, 4-H, FFA, ethical practices, youth livestock shows 


\section{ABSTRACT \\ Perceptions of Ethical Practices in Youth Livestock Shows}

\section{Sharon J. Ankrom}

This study was designed to evaluate the perceptions of 4-H and FFA youth and their parents of the ethical nature of practices used in livestock shows. A questionnaire was designed to determine the ethical perceptions of 23 commonly used livestock practices. A purposeful population consisted of 4-H and FFA livestock exhibitors from Pennsylvania and West Virginia. A total of 109 youth and 67 adults were included in the survey. Overall the population perceived the 23 practices unethical. This study found significant differences existed between whether or not participants attended an ethics training course, gender and age. Participants that attended and ethics training course found more practices to be unethical compared to participants that did not attend an ethics training course. 


\section{ACKNOWLEDGEMENTS}

I would like to first thank my parents because with out them I would not be writing this thesis. Thank you Dad for providing the means for me to get the things I wanted. Thanks Mom for driving me everywhere for 4-H and sheep shows. Without 4-H I would not be writing this thesis so thanks to my parents I joined 4-H. I would like to thank my brothers, Jason, Matthew and Billy for being there, helping me and making me aware of my dream. I would like to also thank my sister, Laura. Overall, my family always let me do what I wanted and that has shaped me today. Through all the 4-H experiences I realized what gave me a heartbeat and what it took to make my heart beat.

Thanks to my other half, Russell. Because of his encouragement I was able to complete my Bachelor's degree and now my Master's degree. He gave me the motivation and the support from the past, present and future.

Thanks to my committee, Dr. Harry Boone, Dr. Debby Boone, and Dr. Jean Woloshuk. These folks gave me tons of ideas and drive to complete my thesis. They never told me that I was crazy but gave me the encouragement to complete my idea. Thanks to Mr. H.R. Scott for the use of the instrument used for this study. Thank you Ms. Alice Compton for her time it took to make all the copies for my study.

I also wanted to thank Dr. Inskeep and Dr. Cochrane from the Animal Science department for their help when I was an undergraduate. 


\section{TABLE OF CONTENTS}

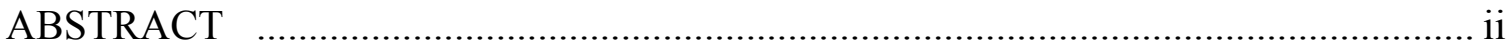

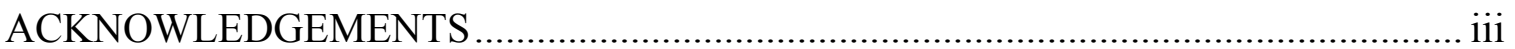

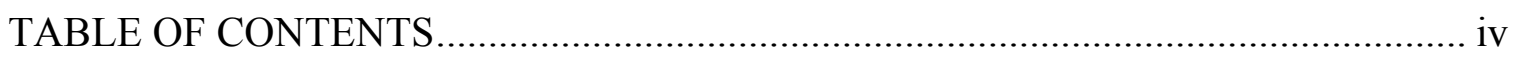

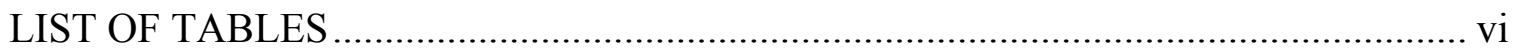

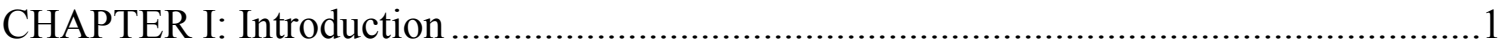

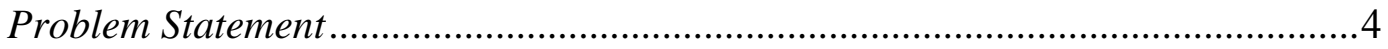

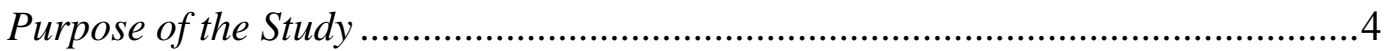

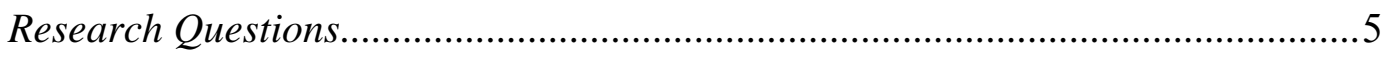

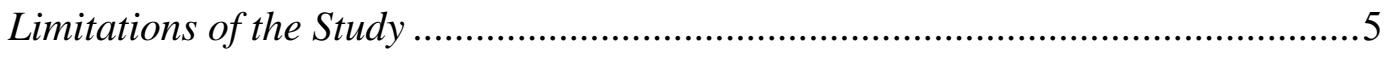

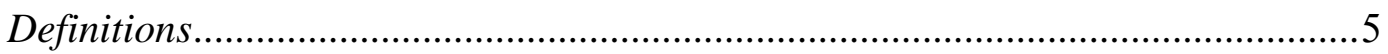

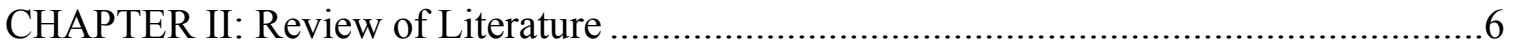

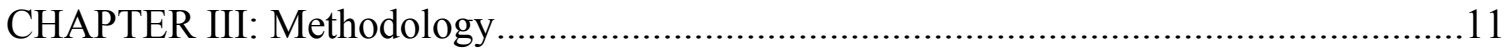

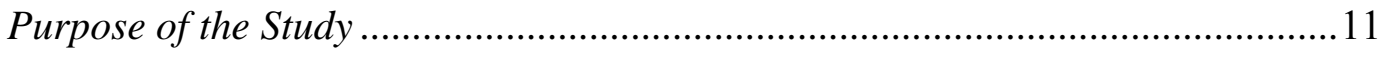

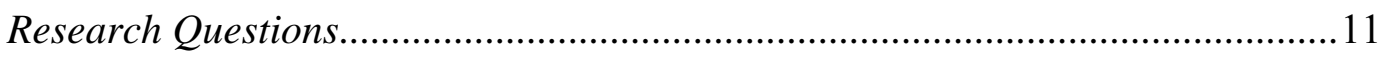

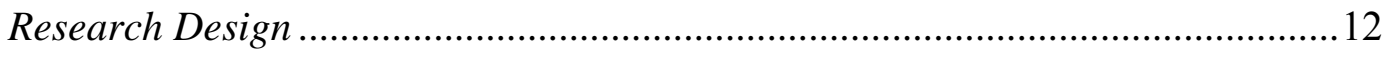

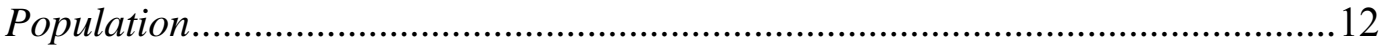

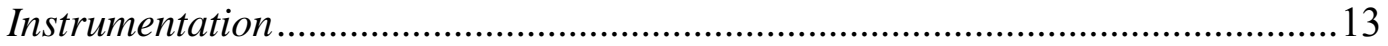

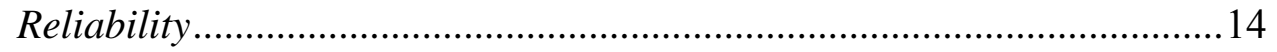

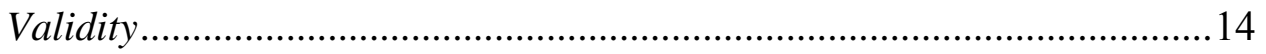

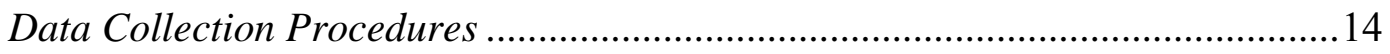

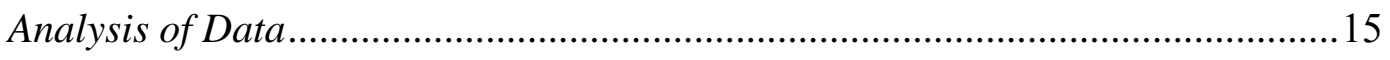

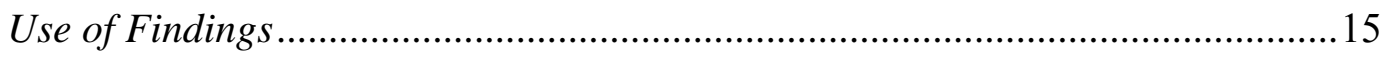

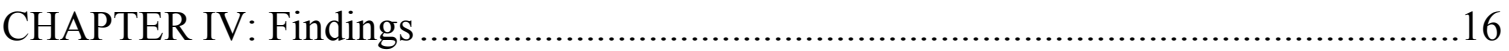

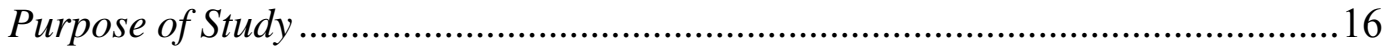

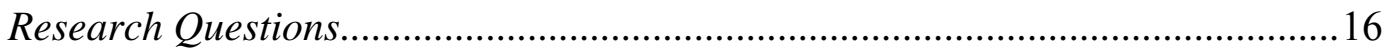

Demographic Characteristics of Population ....................................................... 17

Perception of the Ethical Nature of Commonly Used Livestock Practices ...........21

Comparison of Respondents by Ethics Training, Gender, and Age .......................33

Type of Livestock and Where Exhibited ..................................................................35

What does Livestock Ethnics Mean to Respondents? ...........................................41

Other Ethical Concerns Not Addressed in the Survey .........................................42 


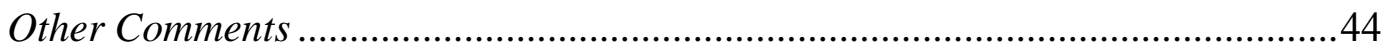

CHAPTER V: Summary, Conclusions, Recommendations ..............................................46

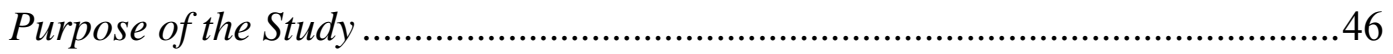

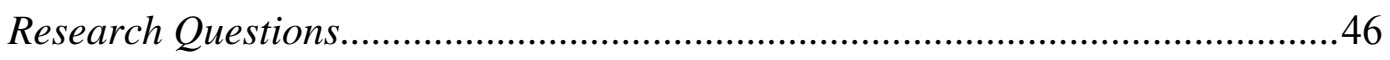

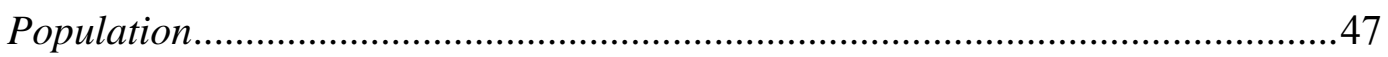

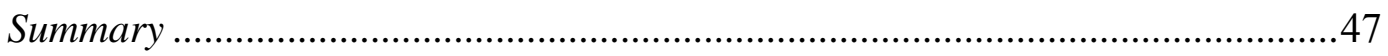

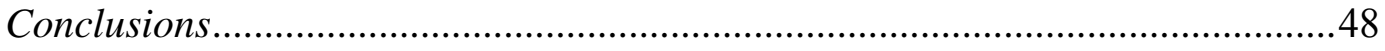

Recommendations …………………..............................................................49

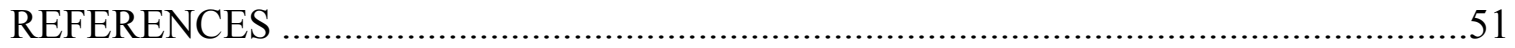

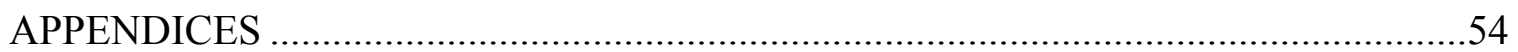

APPENDIX A: Cover Letter to Youth Participants ..................................................55

APPENDIX B: Cover Letter to Parents of Youth Participants............................................57

APPENDIX C: Cover Letter to Parent Participants ........................................................59

APPENDIX D: Follow-Up Letter to Youth Participants...................................................61

APPENDIX E: Follow-Up Letter to Parents of Youth Participants .....................................63

APPENDIX F: Follow-Up Letter to Parent Participants ..............................................65

APPENDIX G: Postcard Follow-Up to Youth Participants ...............................................67

APPENDIX H: Postcard Follow-Up to Parent Participants ...............................................69

APPENDIX I: Questionnaire: Youth Participants .......................................................

APPENDIX J: Questionnaire: Parent Participants ……………………………………......80

APPENDIX K: Consent Form for Youth Participants …………………………...............

APPENDIX L: Assent Form for Youth Participants ......................................................94

APPENDIX M: Consent Form for Youth Participants over 18 Years of Age ..................98

APPENDIX N: Checklist for Youth Participants ............................................................103

APPENDIX O: Open-Ended Responses: What does Livestock Ethics Mean to

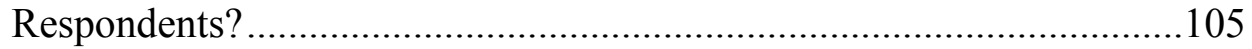

APPENDIX P: Open-Ended Responses: Other Ethical Areas That Should be

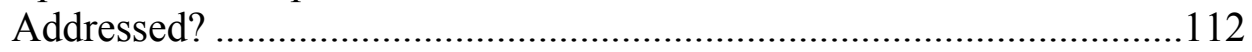

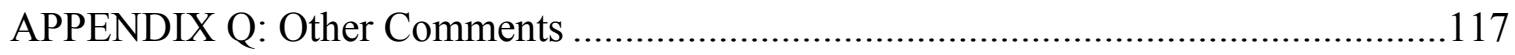

VITA 


\section{LIST OF TABLES}

Table Title Page

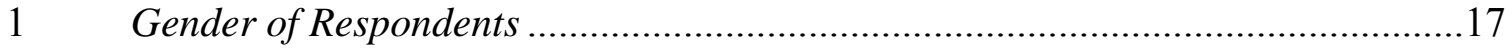

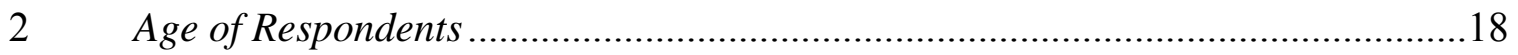

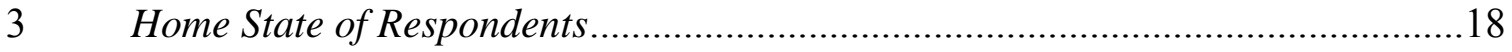

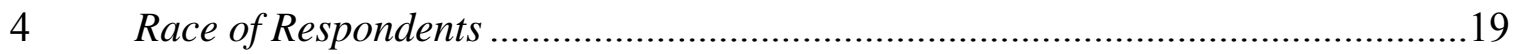

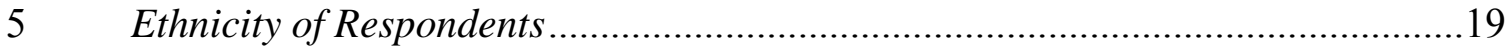

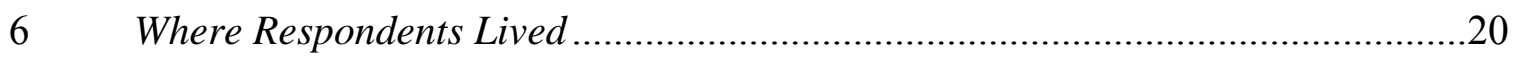

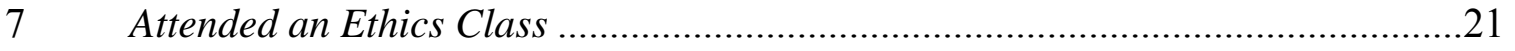

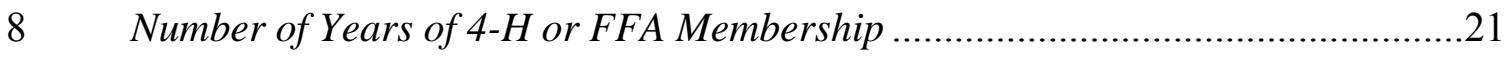

9 Perceptions of the Ethical Nature of “Animal Welfare Issues” "..........................24

10 Perceptions of the Ethical Nature of "Unethical Practices" ...............................26

11 Perceptions of the Ethical Nature of "Potential Fraudulent Practices" ..............28

12 Perceptions of the Ethical Nature of "Deceptive Show Practices” ......................30

13 Perceptions of the Ethical Nature of “Inappropriate Adult/Youth Behaviors” ....32

14 Comparison of Respondents Ethics Training, Gender, and Age ..........................34

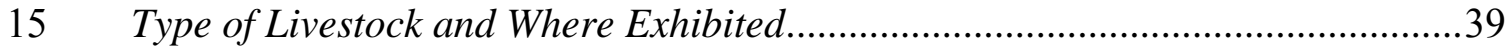

16 Categories of What Livestock Ethics Means Compared to Survey Type ...............42

17 Other Ethical Concerns Not Addressed in the Survey ........................................43

18 Additional Comments Relating to the Survey from Participants .........................45 


\section{CHAPTER I}

Introduction

4-H is the largest and most recognized youth organization recognized in the United States. $4-\mathrm{H}$ is a community of more than six million young people across America learning leadership, citizenship, and life skills (National 4-H Organization, n.d.). This is more youth involved in 4-H than any other leading youth organizations like Boys and Girls Clubs of America, Boy Scouts of America, Girls Scouts USA, FFA and Big Brothers Big Sisters (National 4-H Council as cited by Post, 2007). As part of being a member of a 4-H club, 4-H'ers participate in fun hands on learning activities supported by the latest research of land grant universities (National 4-H Organization, n.d.). According to Cathann Kress (n.d.), Former Director, Youth Development National 4-H Headquarters, "there are three essences of youth development: to engage young people in the work of the land grant universities and United States Department of Agriculture, to teach knowledge and life skills which enhance quality of life, and to create opportunities which promote positive youth development" (p. 4).

Land grant universities are institutes of higher education in the United States, developed under the 1862 Morrill Act and the Hatch Act. Land grant universities mission is to teach agriculture, military tactics, the mechanic arts and home economics (Seevers, Graham, \& Conklin, 2007)). Future Farmers of America (FFA) is an organization to promote and support Agricultural Education (National FFA Organization, n.d.). FFA is a school program based in middle and high school classes (National FFA Organization, n.d.). 4-H is a program that falls under the umbrella of programs that land grant universities support through the Cooperative Extension Service. The United States 
Department of Agriculture is also a contributor to the 4-H program. "The 4-H youth development emphasis is on practical application of knowledge or "learning by doing" to develop skills and acquire a sense of responsibility, initiative and self worth" (Kress, n.d., p.4).

"4-H is part of the Character Counts coalition that has committed to help young people learn the six pillars of character (Hammatt, 2002, p. 2).” The Character Counts, pillars of character are: trustworthiness, respect, responsibility, fairness, caring and citizenship. The projects that the 4-H'ers carry throughout the year are ways to strengthen and improve these positive characteristics. "The mission of the 4-H and youth development program is to assist youth in acquiring knowledge, developing life skills, and forming attitudes that will enable them to become self directing productive, and contributing members of society" (Seevers et al., 2007, p. 9). Within the 4-H program there are numerous projects that 4-H'ers can complete. Topics include home economics, public speaking, tractor safety, gardening, small animals, and large animals. "4-H project work develops the following life skills: decision making, goal setting, planning, implementing and evaluating, communicating, teamwork and cooperation, responsibility, and record keeping” (Mississippi State University Extension Service, n.d., p. 36). 4-H projects are opportunities for youth to gain independence, a sense of belonging, generosity and mastery in a project subject (Kress, n.d.).

One project area that 4-H'er can participate in is livestock projects. "The primary purpose of the youth livestock program is to provide an opportunity for personal growth and development of the young person....young people have the opportunity to develop many positive character traits" (Hammatt, 2002, p. 2). Livestock projects are a great 
opportunity for youth to learn to care for another living thing. As part of a livestock project youth are expected to water, feed, clean, and exercise the animal. The Character Counts values relate to the livestock projects. Trustworthiness promotes proper drug use in the livestock. Respect includes courtesy and proper treatment of people and things. With respect this includes respect of the animal and also respect of the leaders or advisors. Responsibility includes the pursuit of excellence, accountability and perseverance. Perseverance, relating to caring for the livestock project everyday also applies to the show ring, meaning to never give up. Fairness involves consistently applying rules and standards appropriate for different age groups and ability levels. Following what are recommended procedures for fitting and grooming an animal falls under fairness. Caring includes the well-being of people and things in a young person's world. As part of caring this means to provide clean barn/stall for an animal. It denotes action and not just feeling. Citizenship is the last core value, includes making the home, community and country a better place to live for themselves and others. "The purpose of a 4-H project is to create a blue ribbon 4-H'er with a red ribbon pig is more desirable than a red ribbon 4-H'er with a blue ribbon pig" (Mississippi State University Extension Service, n.d., p. 36).

To reward the 4-H member for their hard work with the livestock project they can show their animal at a county fair or other livestock exhibit. At the livestock show they can earn prize money from an animal that places in a livestock class. This prize money should be used as a reward and not the only reason why a 4-H'er should complete a livestock project. 


\section{Problem Statement}

Too often youth get caught up in the "winning" and lose track of the "real values" of a 4$\mathrm{H}$ livestock project. They see the recognition and financial rewards and lose track of the character building activities designed to be a part of the project. Nestor (2000) identified 58 unethical practices observed by Extension Agents and high school teachers in youth livestock shows. Dever (2003) found that females observed a higher incidence of unethical behavior involving ethics and fraudulent practices, while males observed higher incidence of unethical behavior involving adult participation, alteration of animals and animal health and management practices. Scott, Woloshuk, Boone, and Taylor (2008) observed differences in the perceptions of ethical practices between gender, residence type, and participation in ethical training. Are these perceptions common in all groups of youth livestock exhibitors?

\section{Purpose of the Study}

The purpose of the study was to evaluate the perceptions of 4-H and FFA youth and their parents of the ethical nature of practices used in livestock shows. The results will provide Extension Agents and FFA Advisors a better perception of what livestock exhibitors and their parents determine as an ethical or unethical practice in livestock shows. The information may be used in establishing guidelines and trainings for youth and adult volunteer leaders, fair board members, etc., for 4-H and FFA livestock programs. 


\section{Research Questions}

The objectives of the study are reflected in the following research questions:

1. What are youth livestock exhibitor's perceptions of commonly used practices in livestock shows?

2. What are the perceptions of commonly used practices in livestock shows as determined by exhibitor's parents?

3. Are ethics training courses being attended by the livestock exhibitor's and their parents?

4. Do significant differences exist between adults and youth participants when asked about commonly used livestock practices?

5. Are there significant difference between demographic characteristics and perceptions of the ethical nature of commonly used livestock practices?

\section{Limitations of the Study}

One limitation of this study was the accessible population. A group of underage participants and the lack of available contact information provided major obstacles for the researcher. The population used for this study was a purposefully selected group of 4-H and FFA who showed livestock in 2008. Due to the nature of the sample no generalizations can be made to a larger population.

\section{Definitions}

Youth Livestock Exhibitor- 4-H or FFA member who exhibited livestock (breeding cattle, market steers, breeding sheep, market lambs, breeding hogs, market hogs) in the 2008 show season. 


\section{CHAPTER II}

\section{Review of Literature}

"The purpose of 4-H and youth development programs are to assist youth in acquiring knowledge, developing life skills, and forming attitudes that will enable them to become self directing, productive, and contributing members of society" (Seevers, Graham, \& Conklin, 2007, p. 9). From this mission statement of 4-H it is understood that the programs are completely focused on the development of youth, but when working with youth, adults are needed to further the expansion of the youth organization. It is important that the adult helpers/leaders keep in mind that these organizations are focused on the development of the youth. "Ninety seven percent of the time parents are the source of unethical practices" (Wagner as cited in Nestor, 2000, p. 9). Therefore, adult leaders, volunteers and parents need to understand when they have overstepped boundaries that are set up to keep the competition in youth livestock organizations fair. "A 1990 survey of livestock participants associated with one major livestock show revealed that 7.9 percent gave steroids to their animals, $42.5 \%$ gave tranquilizers, and $24.8 \%$ gave diuretics; $37.5 \%$ falsified registration papers; and 25 percent gave illegal drugs " (Goodwin, 2001, p. 1).

There are numerous practices that agriculture educators, extension educators, and 4-H leaders consider unethical (Nestor, 2000; Dever, 2004). Topics that have some showmen on edge at youth livestock shows are illegal uses of drugs, alteration of hair, hooves, or skin by use of paints, professional fitters, and switching ear tags. All of the topics that were deemed unethical primarily were under the influence of adults. Nestor (2000) found the most often unethical topic was adults and youth questioning the 
integrity of the livestock judge because he/she chose one breed over another. This helps to establish the idea that adults are a major influence over the youth who are involved in 4-H and other youth livestock organizations. "An adult, a role model, encouraged, aided and abetted a child in breaking the rules to get ahead" (Nevius, 2003, p. 1). Ethics are a standard of duty and virtue that indicate how we should behave (Josephson Institute, n.d.) An article from the San Antonio Express News (Nevius, 2003) states:

How the wholesome image (of 4-H youth livestock shows) is foundering upon a national scandal, the apparent climax to more than a decade of increasingly cutthroat competition. Since the 1980's the soaring amounts in winners' purses, which can range from several thousand dollars to $\$ 500,000$, have given rise to many ways to cheat: from dye jobs to cosmetic surgery, from hiring professional groomers to injection of vegetable oil or saline solution for smoothing out flabby skin. (p. 12) Anderegg (2003) writes, "The perception that the world is a terribly competitive place makes parents frantic. Working for your child is perceived as being a good parent and some slip over the line and cheat on the children's behalf' (p. 199). According to the National 4-H Competition Task Force (1989), competition has been accepted as an appropriate teaching-learning strategy by many youth organizations, and 4- $\mathrm{H}$ is no exception. But has the huge winnings that can be gained from winning these competitions crossed the line of healthy competition used as a teaching method?

It is important for the adult leaders or educators that are educating youth about ethics that they are internalizing what they are teaching. The adults are teaching youth to be responsible so that these attributes will carry into adulthood, when the adults are not 
keeping true to what they are teaching. One would assume that those teaching about ethical practices would exhibit these qualities and exhibit positive behaviors from teaching character education (Harms, Fritz, \& Rockwell 2004.)

Dr. Jeff Goodwin (1994), who has made several videos talking about the ethics in the show ring, states, "If we teach young people to make good ethical choices in the show ring, there is more of a chance that they will make good ethical choices in everyday life as an adult.” Dr. Goodwin (1994) asks four questions 1) does the practice violate FDA law ? 2) Is the practice fraudulent misrepresentation of the animal? 3) Does practice compromise the welfare of the animal? 4) Does the practice relate to real world agriculture?

Livestock 4-H projects are a great way for young people to be involved with real world agriculture. The youth can understand the feeding, birthing, slaughtering, and byproduct process that all take place in the world of agriculture. "Youth livestock shows can be an effective teaching tool for youth development as well as for agriculturists of the future." (Goodwin, n.d. p.1)

In Ohio, the Department of Agriculture has implemented the Livestock Show Reform Act (Zippay, 2003). This act was put in force to deter cheating in livestock exhibitions and to guard against possible food safety hazards, which can be results of unethical practices in the show ring. The act defines tampering to include injection or administration of products designed to change the condition or appearance of an animal. By exhibitors breaking the laws this jeopardizes the integrity of 4-H livestock shows and sales. After eight exhibition animals from the 1994 Ohio State Fair tested positive for illegal drugs or vegetable oil injected into the animals for cosmetic purposes, Ohio 
became the first state to crack down on people who tamper with livestock to win competitions at fairs (Zippay, 2003).

Not all unethical practices involve the illegal use of drugs. A boy in Texas, whose pig was 10 pounds under the weight limit to be eligible to show, shoved a water hose down the pig's throat and turned on the water. The pig gained the 10 pounds it needed to make the weight limit but died a few minutes later (Goodwin as cited in Nestor, 2000). This is a good example why youth and adults alike need to have the interest of the livestock on their mind. Another example was in Ohio when the grand champion lamb was found with vegetable oil residue in its glands. The boy did this to make the animal appear more muscular (Goodwin as cited in Nestor, 2000). Another instance occurred in Texas where a seventeen year old girl and her family were caught administering a human tranquilizer to her market steer (Goodwin as cited in Nestor, 2000). The attempt was to make the animal calmer in the show ring. In another state there was a young man who had his picture put on the front of the newspaper with his state prize-winning hog. The problem with the picture was that the boy did not raise the best hog in the state. In fact, he had never raised a hog in his life (Goodwin as cited in Nestor, 2000).

According to Brown and Williams (2003) livestock shows try to prohibit unethical practices, but some competitors push the limits of what is acceptable and what is not acceptable. A lot of the times these people pushing the limits of acceptability in livestock show ethics are the parents. The parents make decisions for the youth, and most times the youth are unaware of the practices that their parents are using. Dr. Goodwin from the 1995 National Youth Livestock Program Ethics Symposium, states 
that "the most powerful, effective, and safe way to address this issue (of ethics) is from the kids up" (p.32). By teaching youth good ethics in the show ring, this will hopefully teach youth good ethics in everyday life. Youth complete livestock projects in order to learn by doing, so if they are learning to break rules then will they continue to break rules? According to the Green Lake County UW - Extension (2008), "the main goal of a livestock project is to provide 4-H and FFA members to experience all aspects of raising a meat animal including selection, breeding, fitting marketing, selling and ethical showmanship" (p. 1). There are numerous reasons why people continue to use unethical practices in the show ring, and why they feel they must push the limits of what is acceptable to win. With the fairs of today being overly competitive and large winnings associated with top quality animals, exhibitors are pushed to compete with others. With exhibitors, their parents and others involved with youth livestock shows pushing the boundaries of livestock show ethics, they are threatening the future of youth livestock 4-H projects. 


\section{CHAPTER III}

\section{Methodology}

Purpose of the study

This study was designed to evaluate the perceptions of 4-H and FFA youth and their parents of the ethical nature of practices used in livestock shows. The results will provide Extension Agents and FFA Advisors a better perception of what livestock exhibitors and their parents determine as an ethical or unethical practice in livestock shows. The information may be used in establishing guidelines and trainings for youth and adult volunteer leaders, fair board members, etc., for 4-H and FFA livestock programs.

\section{Research Questions}

The objectives of the study are reflected in the following research questions:

1. What are youth livestock exhibitor's perceptions of commonly used practices in livestock shows?

2. What are the perceptions of commonly used practices in livestock shows as determined by exhibitor's parents?

3. Are ethics training courses being attended by the livestock exhibitor's and their parents?

4. Do significant differences exist between adults and youth participants when asked about commonly used livestock practices?

5. Are there significant differences between demographic characteristics and perceptions of the ethical nature of commonly used livestock practices? 


\section{Research Design}

A descriptive research design was used to evaluate the perceptions of 4-H and FFA youth and their parents of the ethical nature of practices used in livestock shows. Ary, Jacobs, Razavieh, and Sorensen (2006) state that:

Survey research also called descriptive research uses instruments such as questionnaires and interviews to gather information from groups of subjects. Surveys permit the researcher to summarize the characteristics of different groups or to measure their attitudes and opinions toward some issue.

Researchers in education and the social sciences use surveys widely. (p. 31)

\section{Population}

In order to establish the population for this study several steps were taken. First, a letter was mailed to Pennsylvania Extension Educators asking for five names of youth who showed livestock in the 2008 show season. This first letter was mailed to the 67 county Extension Educators who are in charge of 4-H and youth development. The county extension educator's names and address were obtained from The Pennsylvania State University Online Extension Directory. Three weeks later a second mailing was sent to the Pennsylvania Extension Educators. Finally an electronic mailing was sent to those that had not responded.

For the participants from West Virginia, the names and addresses were compiled from a list of the 2008 West Virginia Livestock Round-up participants maintained by the West Virginia University Extension Service. By using these methods a purposeful sample population of 213 youth was established. Once the youth names were received they were entered into an Excel spreadsheet. The purposeful sample was randomly 
divided into two groups. The groups were reviewed and siblings were moved into the same group. The first time siblings were split, they were moved to group 1 . The second time siblings were split they were moved to group 2, etc.

Group 1 was established as the "youth" group with a population of 109 youth. One participant chose not to participate. Group 2 was designated as the "parent" group with a population of 67 adults whose children had shown livestock in 2008. Parents of youth in Group 1 were not included in group 2. One mailing address was undeliverable with no forwarding address. The difference between the sizes of the groups was due to parents with multiple children involved in showing livestock.

There were a total of 43 youth who responded to the survey resulting in a $40 \%$ response rate. Thirty-two parents completed the survey yielding a $48 \%$ response rate.

\section{Instrumentation}

The instrument consisted of a series of questions about common practices that take place when showing livestock. The researcher used an instrument developed by Scott, Woloshuk, Boone and Taylor (2008). There were two versions of the instrument, one for the youth exhibitor participants (group 1) and one for the parents of the youth exhibitor participants (group 2). Both instrument asked the same questions relating to the perceptions of livestock practices. The wording was changed to reflect the youth and parent roles in the process. The participants were instructed to circle whether the practices were ethical, unethical, or not sure according to their perception. There were a total of 23 questions related to the practices in livestock showing and 14 demographic questions. Demographic questions included information about gender, age, race, ethnicity, home state, generalization about where the participant lived. Also included in 
the demographic section were questions that related to the participant's 4-H and FFA experiences. This included questions about the type of project the participant showed in the 2008 show season and also if they had attended a ethics training course.

Reliability. Reliability was established on the instrument using Spearman-Brown split half statistic. The reliability of the instrument was determined to be extensive with a Spearman-Brown coefficient of 0.21 (Robinson, Wrightsman, \& Shaver, 1991).

Validity. In order for an instrument to be relevant to the study the instrument should be valid. Both instruments were presented to a panel of experts to establish content and face validity. The panel of experts consisted of an Extension Specialist and faculty in Agricultural and Extension Education. All the individuals had extensive experiences in 4-H and FFA livestock shows. The panel of experts determined that both instruments had face and content validity.

\section{Data Collection Procedures}

Dillman's (2000) tailored design method was used to communicate with the participants for this study to maximize the response rate. The initial letter to the youth (Group 1) contained a cover letter to the youth that explained the research study, a cover letter to the parents explaining the study, a questionnaire, a consent form for the parents to allow the youth to participate in the study, an assent form for the youth to agree to participate in the study, a checklist to help the participants return the forms, questionnaire, and a self addressed stamped envelope to return the survey. The initial letter to the parents (group 2) contained a cover letter that explained the research study, a questionnaire, and a self addressed stamped envelope to return the survey. 
In order to encourage non-respondents a post card was mailed two weeks after the first mailing was sent. A complete second mailing with the components previously listed was mailed one week after the postcard.

Analysis of Data

The data collected from each respondent were compiled into an Excel spreadsheet and were analyzed using the SPSS data analysis software. Descriptive analyses were performed on the data, and the appropriate methods of reporting central tendency and variability for each type of data were used.

To account for non response error a Chi-Square independence analysis between four variables was calculated. The four variables were age, gender, whether they attended an ethics training course, and ethnicity. "Research has shown that nonrespondents are often similar to late respondents" (Ary et al., 2006, p. 439). The four variables yielded no significant differences. Early respondents were similar to late respondents. Due to the response rate and the way the sample was selected, generalizations were limited to the participants who responded.

\section{Use of Findings}

The findings from this study will be used to draw conclusions about the ethical perceptions of youth and their parents. The information gathered will be shared with county 4-H Extension Agents, agricultural educators, extension specialists, and 4-H administrators in hopes that it will be used to enhance training opportunities available on livestock ethics. 


\section{CHAPTER IV}

\section{Findings}

\section{Purpose of the study}

This study was designed to evaluate the perceptions of 4-H and FFA youth and their parents of the ethical nature of practices used in livestock shows. The results will provide Extension Agents and FFA Advisors a better perception of what livestock exhibitors and their parents determine as an ethical or unethical practice in livestock shows. The information maybe used in establishing guidelines and trainings for youth and adult volunteer leaders, fair board members, etc., for4-H and FFA livestock programs.

\section{Research Questions}

The objectives of the study are reflected in the following research questions:

1. What are youth livestock exhibitor's perceptions of commonly used practices in livestock shows?

2. What are the perceptions of commonly used practices in livestock shows as determined by exhibitor's parents?

3. Are ethics training courses being attended by the livestock exhibitor's and their parents?

4. Do significant differences exist between adults and youth participants when asked about commonly used livestock practices?

5. Are there significant differences between demographic characteristics and perceptions of the ethical nature of commonly used livestock practices? 


\section{Demographic Characteristics of Population}

The respondents for this study consisted of 4-H and FFA members $(\mathrm{N}=43)$ who exhibited livestock in the 2008 show season and parents $(\mathrm{N}=32)$ of youth who exhibited livestock in the 2008 show season in Pennsylvania and West Virginia. Seventeen (39.5 $\%)$ of the youth participants were male and $26(60.5 \%)$ of the youth participants were female. Twelve (38.7\%) of the adult participants were male and $19(61.3 \%)$ of the participants were female (see Table 1).

Table 1

Gender of Respondents

\begin{tabular}{lllll}
\hline & \multicolumn{2}{c}{ Youth } & \multicolumn{2}{c}{ Adult } \\
\cline { 2 - 5 } & $\mathrm{N}$ & $\%$ & $\mathrm{~N}$ & $\%$ \\
\hline Male & 17 & 39.5 & 12 & 38.7 \\
Female & 26 & 60.5 & 19 & 61.3 \\
\hline
\end{tabular}

The age of the participants ranged from 8 to 19 years of age or older for the youth participants and for the adult participants ranged from 31-40 years of age to 51-60 years of age. The majority of the youth participants were 14-18 years of age $(\mathrm{N}=33,76.7 \%)$ and the majority of the adult participants were in the 41-50 years of age category $(\mathrm{N}=23$, $71.9 \%)$ (see Table 2). 
Table 2

Age of Respondents

\begin{tabular}{lcccc}
\hline & \multicolumn{3}{c}{ Youth } & \multicolumn{3}{c}{ Adult } \\
\cline { 2 - 5 } & $\mathrm{N}$ & $\%$ & $\mathrm{~N}$ & $\%$ \\
\hline $8-9$ years of age & 1 & 2.3 & & \\
$10-13$ years of age & 6 & 14.0 & & \\
$14-18$ years of age & 33 & 76.7 & & \\
19 years of age or older & 3 & 7.0 & 5 & 71.9 \\
$31-40$ years of age & & & 23 & 12.5 \\
$41-50$ years of age & & & 4 & \\
$51-60$ years of age & & & & \\
\hline
\end{tabular}

Of the youth respondents, $22(51.2 \%)$ were from Pennsylvania and 21were (48.8 \%) from West Virginia. There were 18 (56.3 \%) adult respondents from Pennsylvania, 13 respondents $(40.6 \%)$ from West Virginia and one respondent $(3.1 \%)$ from another state (see Table 3).

Table 3

Home State of Respondents

\begin{tabular}{lcccc}
\hline & \multicolumn{2}{c}{ Youth } & \multicolumn{3}{c}{ Adult } \\
\cline { 2 - 5 } & $\mathrm{N}$ & $\%$ & $\mathrm{~N}$ & $\%$ \\
\hline Pennsylvania & 22 & 51.2 & 18 & 56.3 \\
West Virginia & 21 & 48.8 & 13 & 40.6 \\
Other & 0 & .0 & 1 & 3.1 \\
\hline
\end{tabular}


There were $42(97.7 \%)$ youth participants that indicated their race was white and one $(2.3 \%)$ youth participant who indicated he/she was American Indian or Alaskan Native. Thirty-two (100\%) of the adult participants indicated their race was white (see Table 4).

Table 4

Race of Respondents

\begin{tabular}{lcccc}
\hline & \multicolumn{3}{c}{ Youth } & \multicolumn{2}{c}{ Adult } \\
\cline { 2 - 5 } & $\mathrm{N}$ & $\%$ & $\mathrm{~N}$ & $\%$ \\
\hline $\begin{array}{l}\text { American Indian or Alaskan } \\
\text { Native }\end{array}$ & 1 & 2.3 & 0 & .0 \\
White & 42 & 97.7 & 32 & 100.0 \\
\hline
\end{tabular}

One youth (2.4\%) participant indicated their ethnicity was of Hispanic origin and $40(97.6 \%)$ indicated they were of Non-Hispanic origin. Thirty $(100 \%)$ of the adults indicated that they were of Non-Hispanic origin (see Table 5).

Table 5

Ethnicity of Respondents

\begin{tabular}{lcccc}
\hline & \multicolumn{2}{c}{ Youth } & \multicolumn{3}{c}{ Adult } \\
\cline { 2 - 5 } & $\mathrm{N}$ & $\%$ & $\mathrm{~N}$ & $\%$ \\
\hline Hispanic origin & 1 & 2.4 & 0 & .0 \\
Non-Hispanic origin & 40 & 97.6 & 30 & 100.0 \\
\hline
\end{tabular}

Twenty-eight youth respondents $(65.1 \%)$ lived on a farm or ranch, $14(32.6 \%)$ lived in a town with a population under 10,000 or rural non farm and one $(2.3 \%)$ lived in a city with a population over 50,000. Twenty-five adult respondents $(78.1 \%)$ lived on a 
farm or ranch, three $(9.4 \%)$ lived in a town with a population under 10,000 or rural non farm, two (6.3\%) lived in a town or city with a population of 10,000 to 50,000 , and two (6.3\%) lived in a city with a population over 50,000 (see Table 6).

Table 6

Where the Respondents Lived

\begin{tabular}{lcccc}
\hline & \multicolumn{2}{c}{ Youth } & \multicolumn{2}{c}{ Adult } \\
\cline { 2 - 5 } & $\mathrm{N}$ & $\%$ & $\mathrm{~N}$ & $\%$ \\
\hline Farm or ranch & 28 & 65.1 & 25 & 78.1 \\
$\begin{array}{l}\text { A town with a population under } \\
10,000 \text { or rural non farm }\end{array}$ & 14 & 32.6 & 3 & 9.4 \\
$\begin{array}{l}\text { Town or city with a population of } \\
10,000 \text { to 50,000 }\end{array}$ & 0 & .0 & 2 & 6.3 \\
$\begin{array}{l}\text { City with a population over } \\
50,000\end{array}$ & 1 & 2.3 & 2 & 6.3 \\
\hline
\end{tabular}

The respondents were asked whether they had attended an ethics training class. Thirty-five ( $81.4 \%$ ) of the youth indicated they had attended an ethics class while eight (18.6\%) youth had not attended an ethics training. Twenty-four (75.0 \%) adult respondents indicated they had attended an ethics training class while eight $(25.0 \%)$ respondents had not attended an ethics training class (see Table 7). 
Table 7

Attended an Ethics Class

\begin{tabular}{lcccc}
\hline & \multicolumn{3}{c}{ Youth } & \multicolumn{3}{c}{ Adult } \\
\cline { 2 - 5 } & $\mathrm{N}$ & $\%$ & $\mathrm{~N}$ & $\%$ \\
\hline No & 8 & 18.6 & 8 & 25.0 \\
Yes & 35 & 81.4 & 24 & 75.0 \\
\hline
\end{tabular}

Respondents were asked if they had been a member of the 4-H or FFA programs and how long they were members. Youth participants had been a member of 4-H for an average of 6.67 years $(S D=2.59)$. Youth respondents had been a member of the FFA for an average .91 years $(S D=1.34)$. Adult respondents had been a member of $4-\mathrm{H}$ for an average of 8.04 years $(S D=4.45)$ and had been involved in the FFA for an average of 1.65 years $(S D=2.08)($ see Table 8$)$.

Table 8

Number of Years of 4-H or FFA Membership

\begin{tabular}{lrccc}
\hline & \multicolumn{3}{c}{ Youth } & \multicolumn{3}{c}{ Adult } \\
\cline { 2 - 5 } & $M$ & $S D$ & $M$ & $S D$ \\
\hline 4-H Membership & 6.67 & 2.59 & 8.04 & 4.45 \\
FFA Membership & .91 & 1.34 & 1.65 & 2.08 \\
\hline
\end{tabular}

Perception of the Ethical Nature of Commonly Used Livestock Practices

The respondents were asked to indicate their perceptions of the ethical nature of 23 commonly used livestock practices. The 23 practices were divided into five categories which include "animal welfare issues," "unethical practices," "potential fraudulent 
actions," "deceptive show practices," and "inappropriate youth and adult behaviors" (see Table 9).

The "animal welfare issues" category consisted of eight practices which included: cutting lambs' tails too close, hitting uncooperative animals, leaving lambs in trimming chutes for extended periods of time, pulling a lamb's head where its feet leave the ground, restrictive feeding of an animal, running overweight animals, using mechanical equipment to teach animals to lead and using sedative type drugs on animals. For the "animal welfare issues" category the majority of the youth participants indicated that all eight practices were unethical. Twenty-seven (64.3\%) of the youth participants indicted that cutting lambs' tails too close was unethical while seven (16.7 \%) indicated that it was ethical and eight (19.0\%) were unsure of the practice. Thirty-four (81.0\%) of the youth indicated that hitting uncooperative animals was unethical, three (7.1\%) indicated it was ethical and five (11.9\%) were unsure of the practice. For the practice of leaving lambs in trimming chutes for extended periods of time, 33 respondents $(78.6 \%)$ indicated it was unethical, and nine (21.4\%) indicated that they were unsure of the practice. Twenty-five (59.5\%) youth indicated that pulling a lamb's head until its feet leave the ground was unethical, 10 respondents $(23.8 \%)$ indicated that it was an unethical practice and seven individuals (16.7\%) indicated they were unsure. Twenty respondents (47.6 \%) indicated that restrictive feeding of an animal was unethical, 19 (45.2\%) of the respondents indicated that the practice was ethical and three $(7.1 \%)$ were unsure. Running overweight animals was perceived as unethical by 23 (54.8\%) of the youth respondents, $15(35.7 \%)$ indicated that the practice was ethical and four (9.5\%) indicated they were unsure. Twenty-three $(57.5 \%)$ of the respondents indicated that it was unethical to use 
mechanical equipment to teach animals to lead, nine $(22.5 \%)$ said it was ethical, and eight $(20 . \%)$ were unsure of the practice. Thirty of the respondents said it was unethical to use sedative type drugs on animals, five (11.9\%) indicated that the practice was ethical and seven $(16.7 \%)$ were unsure of the practice.

The adult respondents were also asked their perceptions on the same "animal welfare issues" commonly used livestock practices. Twenty-one respondents $(65.6 \%)$ indicated that cutting lambs' tails too close was unethical, two $(6.3 \%)$ indicated that the practice was ethical and nine $(28.1 \%)$ were unsure. Twenty-four $(75.0 \%)$ indicated that hitting uncooperative animal was unethical, three $(6.3 \%)$ perceive the practice as ethical and five $(15.6 \%)$ are unsure. Leaving lambs in trimming chutes for extended periods of time was perceived unethical by 22 of the adults surveyed (68.8 \%) two individuals (6.3 $\%)$ indicated the practice was ethical and eight (25.0\%) were unsure. Seventeen $(53.1 \%)$ adults perceived that pulling a lamb's head until its feet leave the ground was unethical while nine $(28.1 \%)$ indicated the practice was ethical and six $(18.8 \%)$ indicated they were unsure. The practice of restrictive feeding of an animal was unethical according to $13(40.6 \%)$ of the adults $13(40.6 \%)$ perceived the practice as ethical and six $(18.8 \%)$ were unsure. Sixteen $(50.0 \%)$ of the adults indicated that running overweight animals was unethical $10(31.3 \%)$ indicated it was ethical and six (18.8) were unsure. Fifteen (46.9\%) adults indicated that using mechanical equipment to teach animals to lead was unethical, eight $(25.0 \%)$ indicated the practice was ethical and nine $(28.1 \%)$ were not sure. Twenty-four (77.4\%) of the adults indicated that using sedative drugs on animals was unethical three $(9.7 \%)$ indicated that the practice was ethical, and four $(12.9 \%)$ of the adults were not sure (see Table 9). 
Table 9

Perceptions of the Ethical Nature of "Animal Welfare Issues"

\begin{tabular}{|c|c|c|c|c|c|c|c|c|c|c|c|c|}
\hline & \multicolumn{6}{|c|}{ Youth } & \multicolumn{6}{|c|}{ Adult } \\
\hline & \multicolumn{2}{|c|}{ unethical } & \multicolumn{2}{|c|}{ ethical } & \multicolumn{2}{|c|}{ not sure } & \multicolumn{2}{|c|}{ unethical } & \multicolumn{2}{|c|}{ ethical } & \multicolumn{2}{|c|}{ not sure } \\
\hline & $\mathrm{N}$ & $\%$ & $\mathrm{~N}$ & $\%$ & $\mathrm{~N}$ & $\%$ & $\mathrm{~N}$ & $\%$ & $\mathrm{~N}$ & $\%$ & $\mathrm{~N}$ & $\%$ \\
\hline Cutting lambs' tails too close is: & 27 & 64.3 & 7 & 16.7 & 8 & 19.0 & 21 & 65.6 & 2 & 6.3 & 9 & 28.1 \\
\hline Hitting uncooperative animals is: & 34 & 81.0 & 3 & 7.1 & 5 & 11.9 & 24 & 75.0 & 3 & 9.4 & 5 & 15.6 \\
\hline $\begin{array}{l}\text { Leaving lambs in trimming chutes } \\
\text { for extended periods of time is: }\end{array}$ & 33 & 78.6 & 0 & .0 & 9 & 21.4 & 22 & 68.8 & 2 & 6.3 & 8 & 25.0 \\
\hline $\begin{array}{l}\text { Pulling a lamb's head where its feet } \\
\text { leave the ground is: }\end{array}$ & 25 & 59.5 & 10 & 23.8 & 7 & 16.7 & 17 & 53.1 & 9 & 28.1 & 6 & 18.8 \\
\hline Restrictive feeding of an animal is: & 20 & 47.6 & 19 & 45.2 & 3 & 7.1 & 13 & 40.6 & 13 & 40.6 & 6 & 18.8 \\
\hline Running overweight animals is: & 23 & 54.8 & 15 & 35.7 & 4 & 9.5 & 16 & 50.0 & 10 & 31.3 & 6 & 18.8 \\
\hline $\begin{array}{l}\text { Using mechanical equipment to } \\
\text { teach animals to lead is: }\end{array}$ & 23 & 57.5 & 9 & 22.5 & 8 & 20.0 & 15 & 46.9 & 8 & 25.0 & 9 & 28.1 \\
\hline $\begin{array}{l}\text { Using sedative type drugs on animals } \\
\text { is: }\end{array}$ & 30 & 71.4 & 5 & 11.9 & 7 & 16.7 & 24 & 77.4 & 3 & 9.7 & 4 & 12.9 \\
\hline
\end{tabular}


The "unethical practices" category consisted of five practices. The five practices include: adults coaching youth from the sidelines, adults preparing animals for youth, adults sharing preparation of animals with the youth, animals cared for by someone other than the exhibitor, and grooming of animals by professionals. Twenty-three of the youth (54.8\%) said that adults coaching a youth from the sidelines was unethical, 16 (38.1\%) indicated that the practice was ethical and three $(7.1 \%)$ were unsure. Twenty-nine of the youth respondents $(69.0 \%)$ indicated that adults preparing animals for youth was an unethical practices, six (14.3\%) responded that the practice was ethical and seven (16.7 $\%)$ were unsure of the practice. Three of the respondents (7.1\%) perceived that adults sharing preparation of animals with the youth was unethical, 38 youth $(90.5 \%)$ responded that the practice was ethical and one (2.4\%) was unsure. For the practice of animals cared for by someone other than the exhibitor, 36 of the youth $(85.7 \%)$ indicated that the practice was unethical, four (9.5\%) indicated it was ethical, and two (4.8\%) indicated they were unsure. Twenty-two (52.4\%) of the respondents indicated that grooming of animals by professionals was unethical, $18(42.9 \%)$ said it is ethical, and two (4.8\%) indicated that they were unsure of the practice (see Table 10). 
Table 10

Perceptions of the Ethical Nature of "Unethical Practices"

\begin{tabular}{|c|c|c|c|c|c|c|c|c|c|c|c|c|}
\hline & \multicolumn{6}{|c|}{ Youth } & \multicolumn{6}{|c|}{ Adult } \\
\hline & \multicolumn{2}{|c|}{ Unethical } & \multicolumn{2}{|c|}{ Ethical } & \multicolumn{2}{|c|}{ Not Sure } & \multicolumn{2}{|c|}{ Unethical } & \multicolumn{2}{|c|}{ Ethical } & \multicolumn{2}{|c|}{ Not Sure } \\
\hline & $\mathrm{N}$ & $\%$ & $\mathrm{~N}$ & $\%$ & $\mathrm{~N}$ & $\%$ & $\mathrm{~N}$ & $\%$ & $\mathrm{~N}$ & $\%$ & $\mathrm{~N}$ & $\%$ \\
\hline $\begin{array}{l}\text { Adults coaching youth from the } \\
\text { sidelines is: }\end{array}$ & 23 & 54.8 & 16 & 38.1 & 3 & 7.1 & 14 & 45.2 & 11 & 35.5 & 6 & 19.4 \\
\hline Adults preparing animals for youth is: & 29 & 69.0 & 6 & 14.3 & 7 & 16.7 & 22 & 68.8 & 5 & 15.6 & 5 & 15.6 \\
\hline $\begin{array}{l}\text { Adults sharing preparation of animals } \\
\text { with the youth is: }\end{array}$ & 3 & 7.1 & 38 & 90.5 & 1 & 2.4 & 1 & 3.1 & 30 & 93.8 & 1 & 3.1 \\
\hline $\begin{array}{l}\text { Animals cared for by someone other } \\
\text { than the exhibitor is: }\end{array}$ & 36 & 85.7 & 4 & 9.5 & 2 & 4.8 & 22 & 73.3 & 6 & 20.0 & 2 & 6.7 \\
\hline $\begin{array}{l}\text { Grooming of animals by professionals } \\
\text { is: }\end{array}$ & 22 & 52.4 & 18 & 42.9 & 2 & 4.8 & 23 & 71.9 & 6 & 18.8 & 3 & 9.4 \\
\hline
\end{tabular}


Adults were also asked their perception of "unethical practices." Fourteen adults (45.2\%) indicated that adults coaching youth from the sidelines was unethical, 11 adults (35.5\%) indicated it was ethical and six (19.4\%) were unsure. Twenty-two adults (68.8 $\%)$ indicated that adults preparing animals for youth was unethical, five (15.6\%) indicated the practice was ethical and five $(15.6 \%)$ were unsure. One $(3.1 \%)$ of the respondents perceived that adults sharing preparation of animals with the youth was unethical, 30 adults (93.8 \%) perceived this practice as ethical, and one (3.1\%) was not sure. Twenty-two of the adult respondents $(73.3 \%)$ perceived that animals cared for by someone other than the exhibitor was unethical, six (20. \%) indicated that it is ethical and two $(6.7 \%)$ were not sure. Grooming of animals by professionals was perceived to be unethical by $23(71.9 \%)$ of the adult participants, six (18.8\%) indicated that it was ethical and three $(9.4 \%)$ were unsure (see Table 10$)$.

The category of "potential fraudulent actions" consisted of two practices. The two practices include: paying above market value for animals and substituting an animal without notifying the show committee. Ten of the youth respondents $(23.8 \%)$ indicated that it was unethical to pay above market value for animals, 24 (57.1\%) indicated that the practice was ethical and eight (19.0\%) were unsure. Thirty-eight youth $(90.5 \%)$ perceived that substituting an animal without notifying the show committee was unethical, and four (9.5\%) indicated they were unsure of the practice (see Table 11). 
Table 11

Perceptions of the Ethical Nature of "Potential Fraudulent Actions"

\begin{tabular}{|c|c|c|c|c|c|c|c|c|c|c|c|c|}
\hline & \multicolumn{6}{|c|}{ Youth } & \multicolumn{6}{|c|}{ Adult } \\
\hline & \multicolumn{2}{|c|}{ Unethical } & \multicolumn{2}{|c|}{ Ethical } & \multicolumn{2}{|c|}{ Not Sure } & \multicolumn{2}{|c|}{ Unethical } & \multicolumn{2}{|c|}{ Ethical } & \multicolumn{2}{|c|}{ Not Sure } \\
\hline & $\mathrm{N}$ & $\%$ & $\mathrm{~N}$ & $\%$ & $\mathrm{~N}$ & $\%$ & $\mathrm{~N}$ & $\%$ & $\mathrm{~N}$ & $\%$ & $\mathrm{~N}$ & $\%$ \\
\hline $\begin{array}{l}\text { Paying above market value for } \\
\text { animals is: }\end{array}$ & 10 & 23.8 & 24 & 57.1 & 8 & 19.0 & 6 & 19.4 & 18 & 58.1 & 7 & 22.6 \\
\hline $\begin{array}{l}\text { Substituting an animal without } \\
\text { notifying the show committee is: }\end{array}$ & 38 & 90.5 & 0 & .0 & 4 & 9.5 & 30 & 93.8 & 1 & 3.1 & 1 & 3.1 \\
\hline
\end{tabular}


The adult participants also responded to the "potential fraudulent actions." Six adult respondents $(19.4 \%)$ indicated that paying above market value for animals was unethical, $18(58.1 \%)$ perceived this practice as ethical while seven $(22.6 \%)$ were unsure. Thirty adult respondents $(93.8 \%)$ indicated that substituting an animal without notifying the show committee was unethical, one (3.1\%) indicated it was ethical and one $(3.1 \%)$ was unsure of the practice (see Table 11$)$.

The "deceptive show practices" category consisted of five practices. Those five practices included: encouraging an animal to drink a great deal of water, injection of fluids under an animal's skin, pumping air under an animal's skin, use of non-grooming products on an animal, and giving fluids (other than water) to an animal. Twenty-four of the youth respondents $(57.1 \%)$ indicated that encouraging an animal to drink a great deal of water was unethical, $11(26.2 \%)$ indicated that it was ethical and seven $(16.7 \%)$ were unsure of the practice. Thirty-two youth respondents $(76.2 \%)$ perceived the practice of injecting fluids under an animals skin was unethical, two $(4.58 \%)$ indicated the practice was ethical, and eight (19. \%) were unsure. Forty of the youth respondents $(95.2 \%)$ indicated that pumping air under an animal's skin was unethical, one (2.4\%) indicated that the practice was ethical, and one $(2.4 \%)$ was unsure of the practice. Twenty-eight of the youth $(66.7 \%)$ indicated that the use of non-grooming products on an animal was unethical, five (11.9\%) indicated that the practice was ethical, and nine $(21.4 \%)$ were unsure. Twenty-eight of the youth respondents (66.7\%) perceived that giving fluids (other than water) to an animal was unethical, eight (19.0\%) perceived this practice as ethical, and six (14.3\%) were unsure of the practice (see Table 12). 
Table 12

Perceptions of the Ethical Nature of "Deceptive Show Practices"

\begin{tabular}{|c|c|c|c|c|c|c|c|c|c|c|c|c|}
\hline & \multicolumn{6}{|c|}{ Youth } & \multicolumn{6}{|c|}{ Adult } \\
\hline & \multicolumn{2}{|c|}{ Unethical } & \multicolumn{2}{|c|}{ Ethical } & \multicolumn{2}{|c|}{ Not Sure } & \multicolumn{2}{|c|}{ Unethical } & \multicolumn{2}{|c|}{ Ethical } & \multicolumn{2}{|c|}{ Not Sure } \\
\hline & $\mathrm{N}$ & $\%$ & $\mathrm{~N}$ & $\%$ & $\mathrm{~N}$ & $\%$ & $\mathrm{~N}$ & $\%$ & $\mathrm{~N}$ & $\%$ & $\mathrm{~N}$ & $\%$ \\
\hline $\begin{array}{l}\text { Encouraging an animal to drink a } \\
\text { great deal of water is: }\end{array}$ & 24 & 57.1 & 11 & 26.2 & 7 & 16.7 & 17 & 53.1 & 8 & 25.0 & 7 & 21.9 \\
\hline $\begin{array}{l}\text { Injection of fluids under an animal's } \\
\text { skin is: }\end{array}$ & 32 & 76.2 & 2 & 4.8 & 8 & 19.0 & 28 & 90.3 & 0 & .0 & 3 & 9.7 \\
\hline Pumping air under an animal's skin is: & 40 & 95.2 & 1 & 2.4 & 1 & 2.4 & 31 & 100.0 & 0 & .0 & 0 & .0 \\
\hline $\begin{array}{l}\text { Use of non-grooming products on an } \\
\text { animal is: }\end{array}$ & 28 & 66.7 & 5 & 11.9 & 9 & 21.4 & 21 & 65.6 & 3 & 9.4 & 8 & 25.0 \\
\hline $\begin{array}{l}\text { Giving fluids (other than water) to an } \\
\text { animal is: }\end{array}$ & 28 & 66.7 & 8 & 19.0 & 6 & 14.3 & 24 & 75.0 & 3 & 9.4 & 5 & 15.6 \\
\hline
\end{tabular}


Adult respondents also responded to the "deceptive show practices" items. Seventeen of the adult respondents (53.1\%) indicated that encouraging an animal to drink a great deal of water was unethical, eight (25.0\%) marked ethical and seven (21.9 $\%)$ were not sure. Twenty-eight adults $(90.3 \%)$ perceived that injecting fluids under an animal's skin was unethical and three $(9.7 \%)$ were unsure of the practice. Thirty-one $(100.0 \%)$ of the respondents perceived that pumping air under an animal's skin was unethical. Twenty-one adults (65.6\%) indicated that the use of non-grooming products on an animal was unethical, three $(9.4 \%)$ indicated that the practice was ethical and eight $(25.0 \%)$ were not sure. Twenty-four adults $(75.0 \%)$ perceived that giving fluids (other than water) to an animal was unethical, three $(9.4 \%)$ indicated that the practice was ethical, and five (15.6\%) were not sure (see Table 12).

There were three practices in the "inappropriate youth and adult behaviors" category. Those three practices included: adults questioning the livestock judge, talking to the judge(s) before as how, and youth questioning the livestock judge. Twenty-four of the youth respondents $(57.1 \%)$ indicated that it was unethical for adults to question the livestock judge, ten $(23.8 \%)$ perceived this practices as ethical, and eight (19.0\%) were unsure. Talking to the judge before a show was perceived as unethical by 26 of the youth (63.4\%), 13 youth (31.7\%) indicated that the practice was ethical, and two (4.9\%) were unsure of the practice. Twenty-one of the youth (51.2\%) perceived that the practice of youth questioning the livestock judge was unethical, 14 (34.1\%) indicated that the practice was ethical, and six (14.6\%) were unsure (see Table 13). 
Table 13

Perceptions of the Ethical Nature of "Inappropriate Adult/Youth Behaviors"

\begin{tabular}{|c|c|c|c|c|c|c|c|c|c|c|c|c|}
\hline & \multicolumn{6}{|c|}{ Youth } & \multicolumn{6}{|c|}{ Adult } \\
\hline & \multicolumn{2}{|c|}{ Unethical } & \multicolumn{2}{|c|}{ Ethical } & \multicolumn{2}{|c|}{ Not Sure } & \multicolumn{2}{|c|}{ Unethical } & \multicolumn{2}{|c|}{ Ethical } & \multicolumn{2}{|c|}{ Not Sure } \\
\hline & $\mathrm{N}$ & $\%$ & $\mathrm{~N}$ & $\%$ & $\mathrm{~N}$ & $\%$ & $\mathrm{~N}$ & $\%$ & $\mathrm{~N}$ & $\%$ & $\mathrm{~N}$ & $\%$ \\
\hline $\begin{array}{l}\text { Adults questioning the livestock } \\
\text { judge is: }\end{array}$ & 24 & 57.1 & 10 & 23.8 & 8 & 19.0 & 20 & 62.5 & 6 & 18.8 & 6 & 18.8 \\
\hline $\begin{array}{l}\text { Talking to the judge(s) before a show } \\
\text { is: }\end{array}$ & 26 & 63.4 & 13 & 31.7 & 2 & 4.9 & 18 & 56.3 & 5 & 15.6 & 9 & 28.1 \\
\hline $\begin{array}{l}\text { Youth questioning the livestock judge } \\
\text { is: }\end{array}$ & 21 & 51.2 & 14 & 34.1 & 6 & 14.6 & 12 & 37.5 & 11 & 34.4 & 9 & 28.1 \\
\hline
\end{tabular}


Twenty of the adult respondents $(62.5 \%)$ indicated that adults questioning the livestock judge was unethical, six (18.8\%) indicated the practice was ethical, and six $(18.8 \%)$ also were not sure. Eighteen of the respondents $(56.3 \%)$ perceived that talking to the judge before a show was unethical, five (15.6\%) felt it was ethical, and nine (28.1\%) were unsure. Twelve adults $(37.5 \%)$ indicated that youth questioning the livestock judge was an unethical practice, 11 (34.4\%) marked it as an ethical practice, and nine $(28.1 \%)$ were not sure of the practice (see Table 13$)$.

Comparison of Respondents by Ethics Training, Gender, and Age

A Chi-square statistical procedure was used to compare the 23 livestock practices and participation in ethics training, gender and age (youth versus adults). When compared on participation in an ethics training program, significant differences were observed between four practices. There were significant differences between the practices of cutting lambs tails too close $(\chi=6.41)$, grooming of animals by professionals $(\chi=9.22)$, restrictive feeding of an animal $(\chi=6.25)$, and running overweight animals $(\chi=$ 8.36) when compared to whether or not the participants (both youth and adult) had attended an ethics class (see Table14). In all four practices, participants were more likely to rate the practices unethical if they had participated in an ethics training class than participants who had not participated in ethics training (see Table 14).

A significant difference existed between the practice of adults coaching youth from the sidelines $(\chi=6.11)$ when compared by gender (see Table 14). More males (46.4\%) rated this practice ethical than females $(31.8 \%)$. There were also a number of females $(18.2 \%)$ who were unsure of the ethical nature of the practice compared to male respondents $(0.0 \%)$ 
Table 14

Comparison of Responses by Ethics Training, Gender, and Age

\begin{tabular}{|c|c|c|c|c|c|c|c|c|c|c|c|c|c|}
\hline & \multirow{2}{*}{$\begin{array}{l}\text { Chi } \\
\text { Value* }\end{array}$} & \multicolumn{2}{|c|}{ Unethical } & \multicolumn{2}{|c|}{ Ethical } & \multicolumn{2}{|c|}{ Not Sure } & \multicolumn{2}{|c|}{ Unethical } & \multicolumn{2}{|c|}{ Ethical } & \multicolumn{2}{|c|}{ Not Sure } \\
\hline & & $\mathrm{N}$ & $\%$ & $\mathrm{~N}$ & $\%$ & $\mathrm{~N}$ & $\%$ & $\mathrm{~N}$ & $\%$ & $\mathrm{~N}$ & $\%$ & $\mathrm{~N}$ & $\%$ \\
\hline Ethics Training & & \multicolumn{6}{|c|}{ No } & \multicolumn{6}{|c|}{ Yes } \\
\hline Cutting lambs' tails too close is: & 6.41 & 6 & 40.0 & 2 & 13.3 & 7 & 46.7 & 42 & 71.2 & 7 & 11.9 & 10 & 16.9 \\
\hline Grooming of animals by processionals is: & 9.22 & 4 & 26.7 & 9 & 60.0 & 2 & 13.3 & 41 & 69.5 & 15 & 25.4 & 3 & 5.1 \\
\hline Restrictive feeding of an animal is: & 6.25 & 3 & 20.0 & 8 & 53.3 & 4 & 26.7 & 30 & 50.8 & 24 & 40.7 & 5 & 8.5 \\
\hline Gender & & \multicolumn{6}{|c|}{ Male } & \multicolumn{6}{|c|}{ Female } \\
\hline Adults coaching youth from the sidelines is: & 6.11 & 15.0 & 53.6 & 13.0 & 46.4 & 0.0 & 0.0 & 22.0 & 50.0 & 14.0 & 31.8 & 8.0 & 18.2 \\
\hline Age of Respondents & & \multicolumn{6}{|c|}{ Youth } & \multicolumn{6}{|c|}{ Adult } \\
\hline Talking to the judge(s) before a show is: & 8.48 & 26. & 63.4 & 13 & 31.7 & 2 & 4.9 & 18 & 56.3 & 5 & 15.6 & 9 & 28.1 \\
\hline
\end{tabular}


A significant difference existed between the practice of talking to the judge before a show $(\chi=8.48)$ when compared by age of the respondents (youth versus adult) (see Table 14). Youth (31.7\%) were more likely to rate the practice as ethical compared to the adults (15.6\%) while more adults (28.1\%) were more likely to be unsure of the ethical nature of the practice than the youth (4.9\%) (see Table 14).

\section{Type of Livestock and Where Exhibited}

The youth participants were asked to indicate what type of livestock they exhibited and where they exhibited the livestock. Twenty-one (48.8\%) youth exhibited market steers at the county 4-H/FA fair, six (14.0\%) exhibited market steers at the State 4-H/FFA fair, one youth (2.3\%) exhibited at a breed association and six (14.0\%) youth exhibited market steers at other livestock shows. Twenty-four (55.8\%) youth participants exhibited feeder calves at the county 4-H/FFA fair, 17 (39.5\%) youth exhibit feeder calves at the state 4-H/FFA fair, two (4.7\%) youth exhibit at a breed association show and six (14.0\%) exhibit at other livestock shows. Fourteen (32.6\%) youth exhibited beef heifers at the county 4-H/FFA fair, six (14.0\%) show beef heifers at the state 4-H/FFA fair, three $(7.0 \%)$ of the youth participants exhibit beef heifers at a breed association show and four (9.3\%) exhibit beef heifers at other livestock shows. Three (7.0\%) youth participants showed other breeding beef cattle at the county 4-H/FFA fair, one (2.3\%) youth showed other breeding beef cattle at the state level 4-H/FFA fair, one (2.3\%) youth showed at a breed association show and one (2.3\%) youth showed other breeding beef cattle at other livestock shows (see Table 15).

Eighteen (41.9\%) youth exhibited market lambs at county 4-H/FFA fair, five (11.6\%) showed market lambs at the state 4-H/FFA fair, two (4.7\%) showed market 
lambs at breed association shows and four (9.5\%) exhibited market lambs at other livestock shows. Four (9.3\%) of the youth exhibited purebred lambs at county 4-H/FFA shows, four $(9.3 \%)$ exhibited at state 4-H/FFA shows, three (7.0\%) exhibited purebred lambs at breed associations shows, and four (9.3\%) showed purebred lambs at other livestock shows. Five (11.6\%) exhibited other breeding sheep at county 4-H/FFA fair, three $(7.0 \%)$ youth exhibited at the state $4-\mathrm{H} / \mathrm{FFA}$ fair same as breed association fairs, and other livestock shows (see Table 15).

Twenty (46.5\%) of the youth participants exhibited market hogs at a county 4H/FFA fair, nine (20.9\%) of the youth exhibited at the state 4-H/FFA fair, one (2.3\%) youth exhibited market hogs at other livestock shows. Five (11.6\%) youth exhibited purebred hogs at county 4-H/FFA fair, four (9.3\%) exhibited purebred hogs at state 4H/FFA fair, and two (4.7\%) exhibited at breed association shows. One (2.3\%) youth showed other breeding swine at county 4-H/FFA fair and one (3.1\%) youth exhibited other breeding swine at a breed association show. Two (4.7\%) of the youth participants showed dairy cattle at a county 4-H/FFA fair, one (2.3\%) at state 4-H/FFA fair and one (2.3\%) of the youth exhibit dairy cattle at breed association shows (see Table 15).

Two (4.7\%) youth exhibit rabbits at county 4-H/FFA fairs and one (2.3\%) of the youth shows rabbits at the state 4-H/FFA fair. Thirteen (30.2\%) of the youth participants exhibit goats at county 4-H/FFA fair, five (11.9\%) of the youth participants show goats at the state 4-H/FFA fair and four (9.5\%) show goats at other livestock shows. One (2.3\%) of the youth exhibit horses at county 4-H/FFA shows, while two (4.7\%) showed their horses at either a breed association show or other livestock show (see Table 15). 
The adult participants were asked to indicate what livestock species their youth exhibited in the 2008 show season. Fourteen (43.8\%) of the adults had youth that exhibited market steers at the county 4-H/FFA fair, seven (21.9\%) exhibited at state 4H/FFA fair, five (15.6\%) adults had youth who exhibited at breed association fairs and other livestock shows. Twelve (37.5\%) of the adults had youth that exhibited feeder calves at the county 4-H/FFA fair, thirteen (40.6\%) adults had youth that showed at the state 4-H/FFA fair, two $(6.3 \%)$ had children that exhibited feeder calves at breed association shows, and five (15.6\%) of the adults had children that exhibited at other livestock shows with feeder calves. Eleven (34.4\%) of the adults had children that exhibited beef heifers at the county 4-H/FFA fair, seven (21.9\%) adults indicted that their children exhibited at the state 4-H/FFA fair, four (12.5\%) had children that showed beef heifers at breed association shows, and four (12.5\%) indicated their children showed at other livestock shows. Four (12.5\%) adults indicated their children exhibited other breeding beef cattle at a county 4-H/FFA fair and three (9.4\%) of the adult participants had children that exhibited other breeding beef cattle at the state 4-H/FFA fairs, breed association shows, and also other livestock shows (see Table 15).

Sixteen $(50.0 \%)$ adults had children that exhibited market lambs at county 4H/FFA fair, eleven (34.4\%) had children that showed at state 4-H/FFA fair, two (6.3\%) had youth that exhibited market lambs at a breed association show, and seven (21.9\%) had children that exhibited at other livestock shows. Three (9.4\%) of the adults had children who showed purebred lambs at the county 4-H/FFA fair, and two (6.3\%) adults had children that exhibited at a state 4-H/FFA fair. Five (15.6\%) adults had children that exhibited other breeding sheep at county 4-H/FFA fair, and one (3.1\%) adult had a child 
who exhibited at both the state 4-H/FFA fair and also at other livestock shows (see Table $15)$.

Nineteen (59.4\%) adults had children that exhibited market hogs at the county 4H/FFA fair, ten (31.3\%) of the adults indicated that their children exhibited at the state 4H/FFA fair, one (3.1\%) adult indicated their child exhibited at a breed association show, and six (18.8\%) showed market hogs at other livestock shows. One (3.1\%) adult had a child who exhibited other breeding swine at both the county 4-H/FFA fair and the state 4H/FFA fair.

Three (9.4\%) adults had children that exhibited dairy at a county 4-H/FFA fair and one $(3.1 \%)$ had a child that exhibited dairy at the state 4-H/FFA fair and also at other livestock shows. Four $(12.5 \%)$ of the adults had children that exhibited rabbits at the county 4-H/FFA fair, two $(6.3 \%)$ had exhibited at the state $4-\mathrm{H} / \mathrm{FFA}$ fair, and one $(3.1 \%)$ adult had a child that exhibited rabbits at other livestock shows. Nine $(28.1 \%)$ of the adults had children that showed goats at a county 4-H/FFA fair, five had exhibited $(15.6 \%)$ at a state $4-H / F F A$ fair, and three $(9.7 \%)$ adults had children exhibit at other livestock shows. Three (9.4\%) adults had children exhibit horses at a county 4-H/FFA fair and one (3.1\%) adult had a child exhibit at a state $4-\mathrm{H} / \mathrm{FFA}$ fair and also one $(3.1 \%)$ adult had a child that exhibited horses at other livestock shows (see Table 15). 
Table 15

Type of Livestock and Where Exhibited

\begin{tabular}{|c|c|c|c|c|c|c|c|c|c|c|c|c|c|c|c|c|}
\hline & \multicolumn{4}{|c|}{ County 4-H/FFA Fair } & \multicolumn{4}{|c|}{ State 4-H/FFA Fair } & \multicolumn{4}{|c|}{ Breed Associations } & \multicolumn{4}{|c|}{ Other Livestock Shows } \\
\hline & \multicolumn{2}{|c|}{ Youth } & \multicolumn{2}{|c|}{ Adult } & \multicolumn{2}{|c|}{ Youth } & \multicolumn{2}{|c|}{ Adult } & \multicolumn{2}{|c|}{ Youth } & \multicolumn{2}{|c|}{ Adult } & \multicolumn{2}{|c|}{ Youth } & \multicolumn{2}{|c|}{ Adult } \\
\hline & $\mathrm{N}$ & $\%$ & $\mathrm{~N}$ & $\%$ & $\mathrm{~N}$ & $\%$ & $\mathrm{~N}$ & $\%$ & $\mathrm{~N}$ & $\%$ & $\mathrm{~N}$ & $\%$ & $\mathrm{~N}$ & $\%$ & $\mathrm{~N}$ & $\%$ \\
\hline Market steers & 21 & 48.8 & 14 & 43.8 & 6 & 14.0 & 7 & 21.9 & 1 & 2.3 & 5 & 15.6 & 6 & 14.0 & 5 & 15.6 \\
\hline Feeder calves & 24 & 55.8 & 12 & 37.5 & 17 & 39.5 & 13 & 40.6 & 2 & 4.7 & 2 & 6.3 & 6 & 14.0 & 5 & 15.6 \\
\hline Beef heifers & 14 & 32.6 & 11 & 34.4 & 6 & 14.0 & 7 & 21.9 & 3 & 7.0 & 4 & 12.5 & 4 & 9.3 & 4 & 12.5 \\
\hline $\begin{array}{l}\text { Other breeding } \\
\text { beef cattle }\end{array}$ & 3 & 7.0 & 4 & 12.5 & 1 & 2.3 & 3 & 9.4 & 1 & 2.3 & 3 & 9.7 & 1 & 2.4 & 3 & 9.4 \\
\hline Market lambs & 18 & 41.9 & 16 & 50.0 & 5 & 11.6 & 11 & 34.4 & 2 & 4.7 & 2 & 6.3 & 4 & 9.5 & 7 & 21.9 \\
\hline Purebred lambs & 4 & 9.3 & 3 & 9.4 & 4 & 9.3 & 2 & 6.3 & 3 & 7.0 & 0 & .0 & 4 & 9.3 & 0 & .0 \\
\hline $\begin{array}{l}\text { Other breeding } \\
\text { sheep }\end{array}$ & 5 & 11.6 & 5 & 15.6 & 3 & 7.0 & 1 & 3.1 & 3 & 7.0 & 0 & .0 & 3 & 7.0 & 1 & 3.1 \\
\hline Market hogs & 20 & 46.5 & 19 & 59.4 & 9 & 20.9 & 10 & 31.3 & 0 & .0 & 1 & 3.1 & 1 & 2.3 & 6 & 18.8 \\
\hline Purebred hogs & 5 & 11.6 & 0 & .0 & 4 & 9.3 & 0 & .0 & 2 & 4.7 & 0 & .0 & 0 & .0 & 0 & .0 \\
\hline
\end{tabular}


Table 15 (Continued)

Type of Livestock and Where Exhibited

\begin{tabular}{|c|c|c|c|c|c|c|c|c|c|c|c|c|c|c|c|c|}
\hline & \multicolumn{4}{|c|}{ County 4-H/FFA Fair } & \multicolumn{4}{|c|}{ State 4-H/FFA Fair } & \multicolumn{4}{|c|}{ Breed Associations } & \multicolumn{4}{|c|}{ Other Livestock Shows } \\
\hline & \multicolumn{2}{|c|}{ Youth } & \multicolumn{2}{|c|}{ Adult } & \multicolumn{2}{|c|}{ Youth } & \multicolumn{2}{|c|}{ Adult } & \multicolumn{2}{|c|}{ Youth } & \multicolumn{2}{|c|}{ Adult } & \multicolumn{2}{|c|}{ Youth } & \multicolumn{2}{|c|}{ Adult } \\
\hline & $\mathrm{N}$ & $\%$ & $\mathrm{~N}$ & $\%$ & $\mathrm{~N}$ & $\%$ & $\mathrm{~N}$ & $\%$ & $\mathrm{~N}$ & $\%$ & $\mathrm{~N}$ & $\%$ & $\mathrm{~N}$ & $\%$ & $\mathrm{~N}$ & $\%$ \\
\hline $\begin{array}{l}\text { Other breeding } \\
\text { swine }\end{array}$ & 1 & 2.3 & 1 & 3.1 & 0 & .0 & 1 & 3.1 & 1 & 2.3 & 0 & .0 & 0 & .0 & 0 & .0 \\
\hline Dairy & 2 & 4.7 & 3 & 9.4 & 1 & 2.3 & 1 & 3.1 & 1 & 2.3 & 0 & .0 & 0 & .0 & 1 & 3.1 \\
\hline Rabbits & 2 & 4.7 & 4 & 12.5 & 1 & 2.3 & 2 & 6.3 & 0 & .0 & 0 & .0 & 0 & .0 & 1 & 3.1 \\
\hline Goats & 13 & 30.2 & 9 & 28.1 & 5 & 11.9 & 5 & 15.6 & 0 & .0 & 0 & .0 & 4 & 9.5 & 3 & 9.7 \\
\hline Poultry & 0 & .0 & 0 & .0 & 0 & .0 & 0 & .0 & 0 & .0 & 0 & .0 & 0 & .0 & 0 & .0 \\
\hline Horses & 1 & 2.3 & 3 & 9.4 & 0 & .0 & 1 & 3.1 & 2 & 4.7 & 0 & .0 & 2 & 4.7 & 1 & 3.1 \\
\hline Other & 0 & .0 & 0 & .0 & 0 & .0 & 0 & .0 & 0 & .0 & 0 & .0 & 0 & .0 & 0 & .0 \\
\hline
\end{tabular}




\section{What does Livestock Ethics Mean to Respondents?}

The questionnaire had three open-ended questions for participants to complete. Participants were asked: What does "livestock ethics" means to you, and "What other ethical concerns or issues were not covered in this survey?" They were also given the opportunity to offer "other comments." The responses to these questions were categorized and the statements placed into categories to better interpret their meanings.

The question, "what does livestock ethics mean to you were categorized into five groupings. The five categories were titled: sportsmanship, drug use, animal husbandry/welfare, following the rules and cheating. The responses were further divided into adult or youth respondents.

The category of sportsmanship had eight youth respondents and 14 adult respondents. Comments from youth participants included "exhibiting good sportsmanship" another "being cooperative in and out of the show ring." There were two youth and five adult respondents that indicated that livestock ethics means drug use. A youth participant wrote that livestock ethics means "quality of keeping healthy animals without using drugs, or treating your animal with harm."

Ten adults and 10 youth participants indicated that livestock ethics means following the rules. An adult wrote, "livestock ethics means .... is following all rules fairly and no kid should be given special treatment because their parents have a connection.”

There were a total of seven participants, four youth and three adults that indicated that livestock ethics was related to cheating. A youth participant wrote "people taking care of their animals and presenting them for show WITHOUT cheating!" 
Fifty of the responses, 33 youth and 17 adults, were related to animal husbandry or welfare. A youth participant wrote," livestock ethics means correct treatment of animals." An adult participant wrote, "proper care and responsibility for the animals the member has as a project (see Appendix O for all comments)."

Table16

Categories of What Livestock Ethics Means Compared to Survey Type

\begin{tabular}{lcc}
\hline & Youth & Adult \\
\hline Sportsmanship & 8 & 14 \\
Drug Use & 2 & 5 \\
Animal Husbandry and Welfare & 33 & 17 \\
Following the Rules & 10 & 10 \\
Cheating & 4 & 3 \\
\hline
\end{tabular}

Other Ethical Concerns Not Addressed in the Survey

The second open ended question asked, "What other ethical concerns/issues not addressed by this survey would you like to comment?" These responses were divided into six categories, leasing: of animals for youths projects, lambs' tail docking, elaborating on other topics covered by the survey, emphasis on winning, parental involvement, and proper ages of animals. While tail docking was covered in the survey there was enough responses in this question to further elaborate on the topic.

For the category of leasing animals, three adults made comments on this practice. An adult wrote "4-H members leasing market lambs, and the winnings not going to the 4-H member" Lambs' tail docking was indicated by six youth and one adult. One youth 
wrote "if it is too long (the tail) it looks really bad." An adult stated "measuring lambs" tails to the right length is difficult."

Nine youth and 10 adults elaborating on topics that were covered in the survey, such as "I think you hit all of the topics, it is just people need to do the right thing." A total of nine respondents including four youth and nine adults wrote that there is too much emphasis on winning in youth livestock shows. One adult participant stated, "Too much emphasis on winning, mainly due to money received for champion, etc." The category of parental involvement was written about by four youth and five adults. One youth wrote "parents interfering with showing and persuading the judges." Two youth and one adult indicated that proper ages of animals were not covered in the survey. A youth participant wrote "switching birthdates of breeding animals-very unethical!" (see Table 17) (see Appendix P for all comments)

\section{Table17}

Other Ethical Concerns Not Addressed in the Survey

\begin{tabular}{lcc}
\hline & Youth & Adult \\
\hline “Leasing” of Animals & 0 & 3 \\
Lambs' Tail Docking & 6 & 1 \\
Elaborating on Topic in Survey & 9 & 10 \\
Emphasis on Winning & 4 & 9 \\
Parental Involvement & 4 & 5 \\
Proper Age of Animal & 2 & 1 \\
\hline
\end{tabular}




\section{Other Comments}

The final open ended questions asked what comments the participant had about the survey. These comments were also divided into smaller categories to group the comments. The groupings are positive (well wishes for the researcher and also for the future of 4-H and FFA programs), ethical issues that need more attention, and comments that dealt with leaders of the 4-H and FFA programs. Positive thoughts and comments were offered by three youth participants that wrote this and 15 adults. Comments ranged from "thank you for sending this survey", "I hope your research goes well and you are able to help make a difference with our youth-our future!," and "asking many of the correct questions."

There were four comments from adults relating to the role of leaders in the 4-H and FFA programs. One of the adult participants wrote "half of the leaders just turned their head because they didn't see anything wrong with it (when talking about unethical practices that occur at youth livestock shows)." A total of 21 participants commented on ethical issues that need more attention including, eight youth participants and 21 adults. These comments ranged from youth questioning the judge, short tail docking in sheep, and parental involvement (see Table18) (see Appendix Q for all comments). 
Table 18

Additional Comments Relating to the Survey from Participants

\begin{tabular}{lcc}
\hline & Youth & Adult \\
\hline $\begin{array}{l}\text { Positive for researcher and future } \\
\text { 4-H and FFA programs }\end{array}$ & 3 & 12 \\
$\begin{array}{l}\text { Leaders of the 4-H and FFA } \\
\text { programs }\end{array}$ & 0 & 4 \\
$\begin{array}{l}\text { Ethical issues that need more } \\
\text { attention }\end{array}$ & 8 & 13 \\
\hline
\end{tabular}




\section{CHAPTER V}

Summary, Conclusions, Recommendations

Purpose of the study

This study was designed to evaluate the perceptions of 4-H and FFA youth and their parents of the ethical nature of practices used in livestock shows. The results will provide Extension Agents and FFA Advisors a better perception of what livestock exhibitors and their parents determine as an ethical or unethical practice in livestock shows. The information maybe used in establishing guidelines and trainings for youth and adult volunteer leaders, fair board members, etc., for 4-H and FFA livestock programs.

\section{Research Questions}

The objectives of the study are reflected in the following research questions:

1. What are youth livestock exhibitor's perceptions of commonly used practices in livestock shows?

2. What are the perceptions of commonly used practices in livestock shows as determined by exhibitor's parents?

3. Are ethics training courses being attended by the livestock exhibitor's and their parents?

4. Do significant differences exist between adults and youth participants when asked about commonly used livestock practices?

5. Are there significant differences between demographic characteristics and perceptions of ethical nature of the commonly used livestock practices? 


\section{Population}

The population for this study consisted of 4-H and FFA members who exhibited livestock in the 2008 show season and parents of 4-H and FFA exhibitors (youth $\mathrm{N}=43$, parents $\mathrm{N}=32)$. Seventeen $(39.5 \%)$ of the youth participants were male and $26(60.5 \%)$ of the youth participants were female. Twelve (38.7\%) of the adult participants were male and $19(61.3 \%)$ of the participants were female. Of the youth respondents, 22 $(51.2 \%)$ were from Pennsylvania and $21(48.8 \%)$ from West Virginia. There were 18 (56.3\%) adult respondents from Pennsylvania, 13 (40.6\%) from West Virginia and one (3.1\%) from Other. The age of the participants ranged from 8-9 years of age to 19 years of age or older for the youth participants and for the adult participants ranged from 31-60 years of age. A majority of the youth participants were $14-18$ years of age $(\mathrm{N}=33$, $76.7 \%)$ and most of the adult participants were in the $41-50$ years of age category $(\mathrm{N}=23$, $71.9 \%)$

Summary

The summary for this study has been presented using the study's research questions.

Research Question 1. A majority of the youth participants found all practices unethical with the exception of adults sharing preparation of animals with youth and paying above market value for animals.

Research Question 2. A majority of the parents that participated in the study rated all practices unethical with the exception of adults sharing preparation of animals with youth and paying above market value for animals. 
Research Question 3. A majority of both the youth participants and adult participants had attended an ethics training course. Thirty-five $(81.4 \%)$ of the youth participants had attended an ethics training class and twenty-four (75.2\%) adults had participated.

Research Question 4. When comparing youth participants to adult participants the only significant difference between age and ethical perceptions of livestock practices was talking to the judge before a show. Twenty-six (63.4\%) of the youth thought this practice was unethical and $18(56.3 \%)$ adults perceived this as unethical.

Research Question 5. When comparisons were made between males and females, the only significant difference was on the practice, adults coaching youth from sidelines. There were fifteen $(53.6 \%)$ males that perceived this as unethical and $22(50.0 \%)$ of the female respondents perceived this practice as unethical.

\section{Conclusions}

1. When it came to "animal welfare issues" a majority of the respondents found all practices to be unethical.

2. A vast majority of the participants perceive that adults sharing preparation of animals with youth was ethical

3. A majority of both youth and adults perceive that paying above market value for animals was ethical.

4. Participants that attended an ethics training course found more practices to be unethical compared to participants that did not attend an ethics training course.

5. A majority of the population was non-Hispanic ethnicity origin.

6. Most adult and youth respondents lived on a farm 
7. A majority of the participants had attended an ethics training course.

8. More adults perceived that grooming of animals by professionals was unethical compared to the youth.

9. There were more significant differences between livestock practice and respondents that attended an ethics training course than any other comparisons

10. Ethics training courses in general for this population appear to create more ethical awareness 4-H/FFA members and their parents.

11. When comparing gender with adults coaching from the participants perceived the practice was either ethical or unethical.

12. Comparing youth and adults on talking to the judge before a show more youth indicated this unethical than parents, this could be because the youth are competing with each other and this could be perceived as an unfair advantage.

13. Participants rated that paying above market value for animal is an ethical practice.

\section{Recommendations}

Based on the findings of this study, the following recommendations are made:

1. Extension and agricultural educators should try to understand which unethical practices respondents rated as ethical. This includes the philosophy behind their responses.

2. Ethics training courses should be offered more frequently through the show season so more people are made aware of unethical practices.

3. Develop an ethics training course specific to adults to better explain the purpose of livestock projects and the parents' role in them. 
4. The results of this study should be shared with all Extension Educators from Pennsylvania and the West Virginia Livestock Roundup committee.

5. Duplicate the survey and use the youth of the parents that were surveyed and then use the parents of the youth who were surveyed and see if they would parallel each other. 


\section{REFERENCES}

Anderegg, D. (2003). Worried all the time: Overparenting in an age of anxiety and how to stop it. Glencoe, Illinois: Free Express

Ary, D., Jacobs, L. C., Razavieh, A., \& Sorensen, C. (2006). Introduction to research in education (7th ed.). California: Thomson Wadsworth.

Brown, P. F. \& Williams, R. H. (2006). Livestock show ethics as perceived by South Texas FFA members and advisors. The Texas Journal of Agriculture and Natural Resource 19,23-30.

Dever, J. (2003). Practices observed at youth livestock exhibitions by Ohio secondary agricultural educators. Unpublished master's thesis, The Ohio State University: Columbus, Ohio.

Dillman, D. (2000). Mail and internet surveys, the tailored design method ( $2^{\text {nd }}$ ed.). New York: John Wiley \& Sons.

Goodwin, J. (1995). Real world agriculture and the natural animal: The measuring stick for what we do at the livestock show. National Youth Livestock Program Ethics

Goodwin, J. (2001). Livestock shows a lesson in ethics, animal care. Retrieved October 2008 from http://www.avma.org/onlnews/javma/jan01/s011501ss.asp

Goodwin, J. (n.d.) University of Idaho Extension Service, Impact. Pg. 1 http://www.extension.uidaho.edu/impacts/Pdf_00/ImproveYouthLivestock00.pdf

Goodwin, J. (1994). A question of ethics, a step beyond: A Question of ethics, the line in the sand. Three part video series. 
Green Lake County UW- Extension. (2008). Green Lake County extension handbook. Retrieved October 2008 from http://www.uwex.edu/CES/cty/greenlake/documents/HandbookPDF.pdf

Hammatt, D. (2002) “What is the real purpose of 4-H livestock projects?” Louisiana State University Extension Service

Harms, K., Fritz, S., \& Rockwell, K. (2004). The impact of character education curricula on youth educators. Journal of Leadership Education 3, 3. Retrieved December 2008 from http://www.fhsu.edu/jole/issues/JOLE_3_3.pdf

Josephson Institute of Ethics (n.d) Character Counts!. Retrieved September 16, 2008 from www.josephsoninstitute.org

Keith, L. \& Vaughn, P. (1998). The value of 4-H competitive activities as perceived by the parents of 4-H members. Journal of Agriculture Education, 39 (3), 41-50.

Kress, C. (n.d). Essential elements of 4-H youth development. Retrieved October 2008 from http://www.national4-hheadquarters.gov/library/elements.ppt

Mississippi State University Extension Service (n.d).This is 4-H Mississippi State, MS Retrieved from [Powerpoint] http://msucares.com/4h_Youth/volunteer/this_is_4h/section3/this_is_4h_presentat ion\%20_pp2a.ppt

National 4-H Competition Task Force. (1989). Competition in 4-H: A national USDA-ES task force report. United States Department of Agriculture, Washington, D.C.

National 4-H Organization (n.d.). Welcome to 4-H. Retrieved February 13, 2009 from www.4-H.org 
National FFA Organization (n.d.). The FFA Mission. Retrieved July 9, 2009 from http://www.ffa.org/index.cfm?method=c_about.mission

Nestor, J. (2000). Unethical practices in exhibiting animals as observed by West Virginia Extension Agents and high school agriculture teachers. Unpublished master's thesis, West Virginia University, Morgantown, West Virginia.

Nevius, C. W. (2003). "A slippery slope: the new parental ethics teach all the wrong life lessons.” Retrieved October 2008 from http://www.sfgate.com/cgibin/article.cgi?file=/chronicle/archive/2003/10/19/CM23632.DTL

Post, J. (2007). Attitudes of 4-H club leaders toward volunteer training in West Virginia. Unpublished master's thesis. West Virginia University, Morgantown, West Virginia.

Robinson J. P., Shaver P. R., \& Wrightsman L. S. (1991). Criteria for scale selection and evalution. New York: Academic Press.

Scott, H., Woloshuk, J., Boone H., \& Taylor, G. (2008). 4-H and FFA youth and parents' perceptions of livestock ethics. Proceedings of the 2008 AAAE Research Conference 3, 912-924. Retrieved October 2008 from agee.caf.wvu.edu/Research/Naerc-2008/complete_printed_proceedings_6

Seevers, B., Graham, D., Conklin, N. (2007). Education through cooperative extension ( $2^{\text {nd }}$ ed.). Columbus, Ohio: Curriculum Materials Service. Symposium Proceedings. 31-36.

Zippay, A. (2003). Tampering disqualifies champion livestock. Farm and Dairy. Retrieved November 2008 from http://www.farmanddairy.com/news/tamperingdisqualifies-champion-livestock/1013.html 
APPENDICES 


\section{APPENDIX A}

Cover Letter to Youth Participants 
April 8, 2009

Dear 4-H/FFA Livestock Show Exhibitor:

As a 2008 livestock exhibitor you know the importance of fair and ethical practices in all livestock competitions. You have an appreciation for the time and effort that goes into the preparation of livestock for these events. As a livestock exhibitor you also have a unique perspective on these practices. We are interested in your perceptions of the ethical nature of a number of practices that are used to prepare and show livestock. Please take a few moments and share your opinions with us.

I am Sharon Ankrom, a graduate student in Agricultural and Extension Education at West Virginia University. Under the direction of my advisor, Dr. Harry Boone, I am conducting a research study to determine the perceptions of youth and parents regarding the ethical nature of practices commonly used in youth livestock shows. The results of this research study will be used to prepare a thesis to partially fulfill the requirements for a Master of Science degree in Agricultural and Extension Education. The results will provide insight to agricultural education teachers, extension educators and 4-H leaders about the perceptions of youth on the ethical nature of practices involved in showing livestock.

Participation in this research study, while voluntary, will only take a few minutes of your time. You may skip any question you are not comfortable answering or you may quit at any point and return in the partially completed questionnaire. All information will be held as confidential as possible. Survey results will be reported in a summary format and individual responses will not be identifiable. You will notice a code number on the return envelope and this will be used to identify non-respondents for follow up. This code will be destroyed before the data are analyzed. There is no penalty or services withheld if you choose not to participate.

You will also find an ASSENT form enclosed that you will need to complete, initial each page, and sign the final page. You will also find a CONSENT form that your parent or guardian must sign and return. Please return the completed survey, the assent form, and your parent/guardian's consent form in the enclosed envelope.

I thank you in advance for your participation in the study. Please return the completed survey, assent form, and consent form by Friday April 17, 2009 using the enclosed envelope.

Sincerely,

Sharon J. Ankrom

Graduate Student
Harry N. Boone, Jr., Ph.D.

Associate Professor 


\section{APPENDIX B}

Cover Letter to Parents of Youth Participants 
April 8, 2009

Dear 4-H/FFA Livestock Show Exhibitor Parent:

As a parent of a 2008 livestock exhibitor you know the importance of fair and ethical practices in all livestock competitions. You have an appreciation for the time and effort that goes into the preparation of livestock for these events. As livestock exhibitors your son/daughter also has a unique perspective on these practices. We are interested in their perceptions of the ethical nature of a number of practices that are used to prepare and show livestock. We request your consent for your child to participate in this study. Please take a few moments and complete the enclosed consent form.

I am Sharon Ankrom, a graduate student in Agricultural and Extension Education at West Virginia University. Under the direction of my advisor, Dr. Harry Boone, I am conducting a research study to determine the perceptions of youth and parents regarding the ethical nature of practices commonly used in youth livestock shows. The results of this research study will be used to prepare a thesis to partially fulfill the requirements for a Master of Science degree in Agricultural and Extension Education. The results will provide insight to agricultural education teachers, extension educators and 4-H leaders about the perceptions of youth and parents on the ethical nature of practices involved in showing livestock.

Participation in this research study by your child, while voluntary, will only take a few minutes of their time. They may skip any question they are not comfortable answering or they may quit at any point and return in the partially completed questionnaire. All information will be held as confidential as possible. Survey results will be reported in a summary format and individual responses will not be identifiable. You will notice a code number on the return envelope and this will be used to identify non-respondents for follow up. This code will be destroyed before the data are analyzed. There is no penalty or services withheld if you choose not to participate.

I thank you in advance for providing your consent for your child to participate in the study. Please use the enclosed envelope to return the completed consent form along with your child's assent form and completed questionnaire by Friday April 17, 2009.

Sincerely,

Sharon J. Ankrom

Harry N. Boone, Jr, PhD.

Graduate Student Associate Professor 


\section{APPENDIX C}

Cover Letter to Parent Participants 
April 8, 2009

Dear 4-H/FFA Livestock Show Exhibitor Parent:

As a parent of a 2008 livestock exhibitor you know the importance of fair and ethical practices in all livestock competitions. You have an appreciation for the time and effort that goes into the preparation of livestock for these events. As a parent of a livestock exhibitor you also have a unique perspective on these practices. We are interested in your perceptions of the ethical nature of a number of practices that are used to prepare and show livestock. Please take a few moments and share your opinions with us.

I am Sharon Ankrom, a graduate student in Agricultural and Extension Education at West Virginia University. Under the direction of my advisor, Dr. Harry Boone, I am conducting a research study to determine the perceptions of youth and parents regarding the ethical nature of practices commonly used in youth livestock shows. The results of this research study will be used to prepare a thesis to partially fulfill the requirements for a Master of Science degree in Agricultural and Extension Education. The results will provide insight to agricultural education teachers, extension educators and 4-H leaders about the perceptions of youth and parents on the ethical nature of practices involved in showing livestock.

Participation in this research study, while voluntary, will only take a few minutes of your time. You may skip any question you are not comfortable answering or you may quit at any point and return in the partially completed questionnaire. All information will be held as confidential as possible. Survey results will be reported in a summary format and individual responses will not be identifiable. You will notice a code number on the return envelope and this will be used to identify non-respondents for follow up. This code will be destroyed before the data are analyzed. There is no penalty or services withheld if you choose not to participate.

I thank you in advance for your participation in the study. Please return the completed survey by Friday April 17, 2009 using the enclosed envelope.

Sincerely,

Sharon J. Ankrom

Graduate Student
Harry N. Boone, Jr., Ph.D. Associate Professor 


\section{APPENDIX D}

Follow-Up Letter to Youth Participants 
May 1, 2009

Dear 4-H/FFA Livestock Show Exhibitor:

On April 8, we sent you a questionnaire about your perceptions of the ethical nature of a number of practices that are used to prepare and show livestock. As of today, we have not received your reply. Your response is vital to the success of the study. We have enclosed a second copy of the survey and hope you will take the time to complete and return it. If you have already returned the first survey there is no need to complete this one, we sincerely appreciate your participation.

As a 2008 livestock exhibitor you know the importance of fair and ethical practices in all livestock competitions. You have an appreciation for the time and effort that goes into the preparation of livestock for these events. As a livestock exhibitor you also have a unique perspective on these practices. We are interested in your perceptions of the ethical nature of a number of practices that are used to prepare and show livestock. Please take a few moments and share your opinions with us.

I am Sharon Ankrom, a graduate student in Agricultural and Extension Education at West Virginia University. Under the direction of my advisor, Dr. Harry Boone, I am conducting a research study to determine the perceptions of youth and parents regarding the ethical nature of practices commonly used in youth livestock shows. The results of this research study will be used to prepare a thesis to partially fulfill the requirements for a Master of Science degree in Agricultural and Extension Education. The results will provide insight to agricultural education teachers, extension educators and 4-H leaders about the perceptions of youth on the ethical nature of practices involved in showing livestock.

Participation in this research study, while voluntary, will only take a few minutes of your time. You may skip any question you are not comfortable answering or you may quit at any point and return in the partially completed questionnaire. All information will be held as confidential as possible. Survey results will be reported in a summary format and individual responses will not be identifiable. You will notice a code number on the return envelope and this will be used to identify non-respondents for follow up. This code will be destroyed before the data are analyzed. There is no penalty or services withheld if you choose not to participate.

You will also find an ASSENT form enclosed that you will need to complete, initial each page, and sign the final page. You will also find a CONSENT form that your parent or guardian must sign and return. Please return the completed survey, the assent form, and your parent/guardian's consent form in the enclosed envelope. I thank you in advance for your participation in the study. Please return the completed survey, assent form, and consent form by Monday May 11, 2009 using the enclosed envelope.

Sincerely,

Sharon J. Ankrom

Harry N. Boone, Jr., Ph.D.

Graduate Student

Associate Professor 


\section{APPENDIX E}

Follow-up Letter to Parents of Youth Participants 
May 1, 2009

Dear 4-H/FFA Livestock Show Exhibitor Parent:

On April 8, we sent your child a questionnaire about their perceptions of the ethical nature of a number of practices that are used to prepare and show livestock. As of today, we have not received their reply. Their response is vital to the success of the study. We have enclosed a second copy of the survey and hope they will take the time to complete and return it. If they have already returned the first survey there is no need to complete this one, we sincerely appreciate their participation.

As a parent of a 2008 livestock exhibitor you know the importance of fair and ethical practices in all livestock competitions. You have an appreciation for the time and effort that goes into the preparation of livestock for these events. As livestock exhibitors your son/daughter also has a unique perspective on these practices. We are interested in their perceptions of the ethical nature of a number of practices that are used to prepare and show livestock. We request your consent for your child to participate in this study. Please take a few moments and complete the enclosed consent form.

I am Sharon Ankrom, a graduate student in Agricultural and Extension Education at West Virginia University. Under the direction of my advisor, Dr. Harry Boone, I am conducting a research study to determine the perceptions of youth and parents regarding the ethical nature of practices commonly used in youth livestock shows. The results of this research study will be used to prepare a thesis to partially fulfill the requirements for a Master of Science degree in Agricultural and Extension Education. The results will provide insight to agricultural education teachers, extension educators and 4-H leaders about the perceptions of youth and parents on the ethical nature of practices involved in showing livestock.

Participation in this research study by your child, while voluntary, will only take a few minutes of their time. They may skip any question they are not comfortable answering or they may quit at any point and return in the partially completed questionnaire. All information will be held as confidential as possible. Survey results will be reported in a summary format and individual responses will not be identifiable. You will notice a code number on the return envelope and this will be used to identify non-respondents for follow up. This code will be destroyed before the data are analyzed. There is no penalty or services withheld if you choose not to participate.

I thank you in advance for providing your consent for your child to participate in the study. Please use the enclosed envelope to return the completed consent form along with your child's assent form and completed questionnaire by Monday May 11, 2009.

Sincerely,

Sharon J. Ankrom

Graduate Student
Harry N. Boone, Jr., Ph.D.

Associate Professor 


\section{APPENDIX F}

Follow-up Letter to Parent Participants 
May 1, 2009

Dear 4-H/FFA Livestock Show Exhibitor Parent:

On April 8, we sent you a questionnaire about your perceptions of the ethical nature of a number of practices that are used to prepare and show livestock. As of today, we have not received your reply. Your response is vital to the success of the study. We have enclosed a second copy of the survey and hope you will take the time to complete and return it. If you have already returned the first survey there is no need to complete this one, we sincerely appreciate your participation.

As a parent of a 2008 livestock exhibitor you know the importance of fair and ethical practices in all livestock competitions. You have an appreciation for the time and effort that goes into the preparation of livestock for these events. As a parent of a livestock exhibitor you also have a unique perspective on these practices. We are interested in your perceptions of the ethical nature of a number of practices that are used to prepare and show livestock. Please take a few moments and share your opinions with us.

I am Sharon Ankrom, a graduate student in Agricultural and Extension Education at West Virginia University. Under the direction of my advisor, Dr. Harry Boone, I am conducting a research study to determine the perceptions of youth and parents regarding the ethical nature of practices commonly used in youth livestock shows. The results of this research study will be used to prepare a thesis to partially fulfill the requirements for a Master of Science degree in Agricultural and Extension Education. The results will provide insight to agricultural education teachers, extension educators and 4-H leaders about the perceptions of youth and parents on the ethical nature of practices involved in showing livestock.

Participation in this research study, while voluntary, will only take a few minutes of your time. You may skip any question you are not comfortable answering or you may quit at any point and return in the partially completed questionnaire. All information will be held as confidential as possible. Survey results will be reported in a summary format and individual responses will not be identifiable. You will notice a code number on the return envelope and this will be used to identify non-respondents for follow up. This code will be destroyed before the data are analyzed. There is no penalty or services withheld if you choose not to participate.

I thank you in advance for your participation in the study. Please return the completed survey by Monday May 11, 2009 using the enclosed envelope.

Sincerely,

Sharon J. Ankrom

Graduate Student
Harry N. Boone, Jr., Ph.D.

Associate Professor 


\section{APPENDIX G}

Postcard Follow-up to Youth Participants 
On April 8, 2009, I sent you a questionnaire about your perceptions of the ethical nature of a number of practices that are used to prepare and show livestock. As of today, I have not received your reply. Your responses are vital to the success of this project, so please take the time to complete and return it. If you have already returned the first survey, thank you for your contribution to my research.

If you have any questions, please contact me at:

\section{Sharon Ankrom}

Agricultural and Extension Education

Davis College of Agriculture, Forestry, and Consumer Sciences, West Virginia University

2056 Agricultural Sciences Building

P.O. Box 6108

Morgantown, WV 26506

304-293-4832 ext. 4484

sankrom@mix.wvu.edu 


\section{APPENDIX H}

Postcard Follow-up to Parent Participants 
On April 8, 2009, I sent you a questionnaire about your perceptions of the ethical nature of a number of practices that are used to prepare and show livestock. As of today, I have not received your reply. Your responses are vital to the success of this project, so please take the time to complete and return it. If you have already returned the first survey, thank you for your contribution to my research.

If you have any questions, please contact me at:

\section{Sharon Ankrom}

Agricultural and Extension Education

Davis College of Agriculture, Forestry, and Consumer Sciences, West Virginia University

2056 Agricultural Sciences Building

P.O. Box 6108

Morgantown, WV 26506

304-293-4832 ext. 4484

sankrom@mix.wvu.edu 
APPENDIX I

Questionnaire: Youth Participants 


\section{4-H and FFA Youth's Perceptions of Ethical Practices in Youth Livestock Shows}
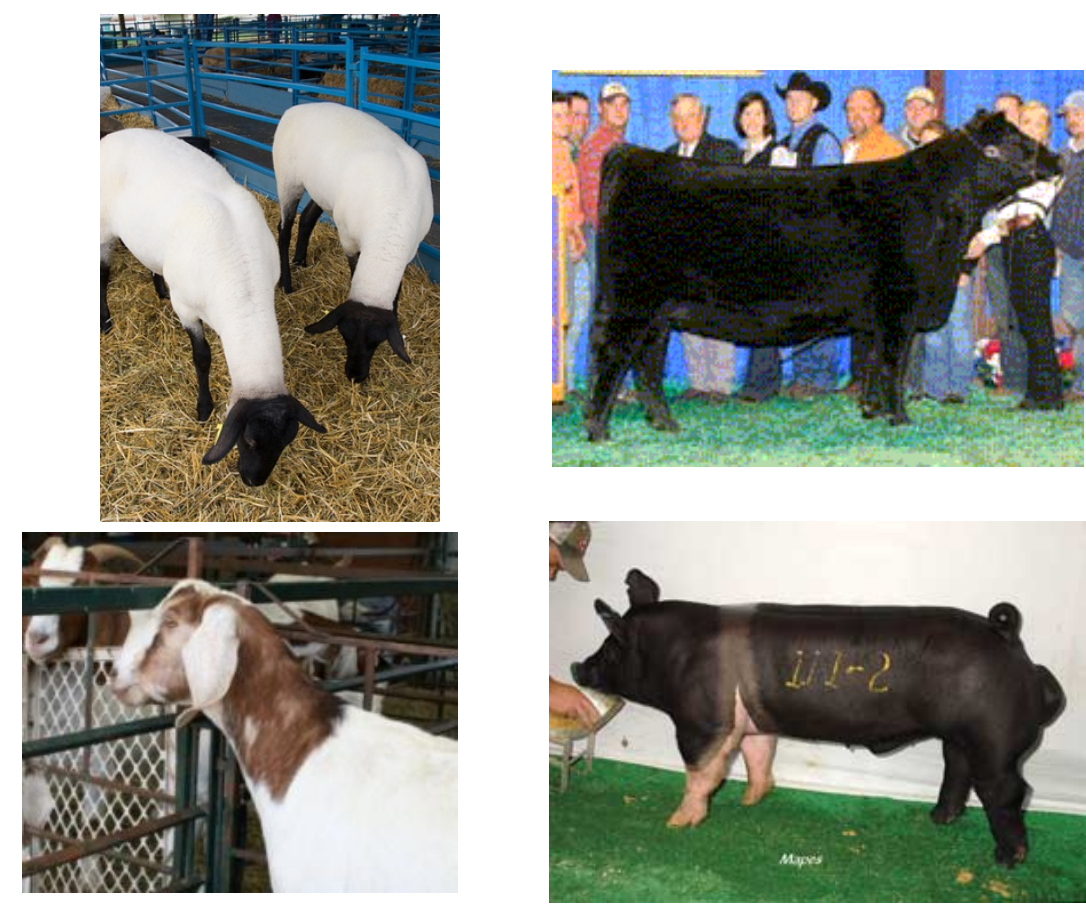

Sharon J. Ankrom

Graduate Student

Agricultural and Extension Education

Davis College of Agriculture, Forestry, and Consumer Sciences

West Virginia University

Morgantown, WV 26505 


\section{4-H and FFA Youth's Perceptions of Ethical Practices in Youth Livestock Shows}

Instructions: Read each of the following statements and indicate your response by circling whether you perceive the practice is unethical, ethical, or you do not know. You should have only one response for each of the statements.

Example: Read the following statement. Assume you perceive that it is ethical for colleges to allow every applicant admission. Circle ethical for your answer.

\begin{tabular}{|c|c|c|c|}
\hline \multicolumn{4}{|c|}{ Example: } \\
\hline Statement & & Response & \\
\hline $\begin{array}{l}\text { Public colleges should admit every student } \\
\text { who submits an application. }\end{array}$ & Unethical & Ethical & Not Sure \\
\hline
\end{tabular}

\begin{tabular}{|c|c|c|c|}
\hline Statement & \multicolumn{3}{|c|}{ Response } \\
\hline $\begin{array}{l}\text { 1. Adults coaching youth from the } \\
\text { sidelines is: }\end{array}$ & Unethical & Ethical & Not Sure \\
\hline 2. Adults preparing animals for youth is: & Unethical & Ethical & Not Sure \\
\hline $\begin{array}{l}\text { 3. Adults questioning the livestock judge } \\
\text { is: }\end{array}$ & Unethical & Ethical & Not Sure \\
\hline $\begin{array}{l}\text { 4. Adults sharing preparation of animals } \\
\text { with the youth is: }\end{array}$ & Unethical & Ethical & Not Sure \\
\hline $\begin{array}{l}\text { 5. Animals cared for by someone other } \\
\text { than the exhibitor is: }\end{array}$ & Unethical & Ethical & Not Sure \\
\hline 6. Cutting lambs' tails too close is: & Unethical & Ethical & Not Sure \\
\hline $\begin{array}{l}\text { 7. Encouraging an animal to drink a great } \\
\text { deal of water is: }\end{array}$ & Unethical & Ethical & Not Sure \\
\hline $\begin{array}{l}\text { 8. Giving fluids (other than water) to an } \\
\text { animal is: }\end{array}$ & Unethical & Ethical & Not Sure \\
\hline
\end{tabular}




\begin{tabular}{|c|c|c|c|}
\hline Statement & \multicolumn{3}{|c|}{ Response } \\
\hline $\begin{array}{l}\text { 9. Grooming of animals by professionals } \\
\text { is: }\end{array}$ & Unethical & Ethical & Not Sure \\
\hline 10. Hitting uncooperative animals is: & Unethical & Ethical & Not Sure \\
\hline $\begin{array}{l}\text { 11. Injection of fluids under an animal's } \\
\text { skin is: }\end{array}$ & Unethical & Ethical & Not Sure \\
\hline $\begin{array}{l}\text { 12. Leaving lambs in trimming chutes for } \\
\text { extended periods of time is: }\end{array}$ & Unethical & Ethical & Not Sure \\
\hline $\begin{array}{l}\text { 13. Paying above market value for animals } \\
\text { is: }\end{array}$ & Unethical & Ethical & Not Sure \\
\hline $\begin{array}{l}\text { 14. Pulling a lamb's head where its feet } \\
\text { leave the ground is: }\end{array}$ & Unethical & Ethical & Not Sure \\
\hline 15. Pumping air under an animal's skin is: & Unethical & Ethical & Not Sure \\
\hline 16. Restrictive feeding of an animal is: & Unethical & Ethical & Not Sure \\
\hline 17. Running overweight animals is: & Unethical & Ethical & Not Sure \\
\hline $\begin{array}{l}\text { 18. Substituting an animal without notifying } \\
\text { the show committee is: }\end{array}$ & Unethical & Ethical & Not Sure \\
\hline 19. Talking to the judge(s) before a show is: & Unethical & Ethical & Not Sure \\
\hline $\begin{array}{l}\text { 20. Use of non-grooming products on an } \\
\text { animal is: }\end{array}$ & Unethical & Ethical & Not Sure \\
\hline $\begin{array}{l}\text { 21. Using mechanical equipment to teach } \\
\text { animals to lead is: }\end{array}$ & Unethical & Ethical & Not Sure \\
\hline 22. Using sedative type drugs on animals is: & Unethical & Ethical & Not Sure \\
\hline $\begin{array}{l}\text { 23. Youth questioning the livestock judge } \\
\text { is: }\end{array}$ & Unethical & Ethical & Not Sure \\
\hline
\end{tabular}


Instructions: Please read each question completely and place a check mark in front of the appropriate response or provide an answer where indicated.

24. What is your gender?

a. Male

b. Female

25. What is your age?

a. $8-9$ years of age

b. $10-13$ years of age

c. $14-18$ years of age

d. 19 years of age or older

26. What is your home state?

$\begin{array}{ll}\text { a. } & \text { Maryland } \\ \text { b. } & \text { Ohio } \\ \text { c. Pennsylvania } \\ \text { d. Virginia } \\ \text { e. West Virginia }\end{array}$

27. Which of the following best describes your race?

a. American Indian or Alaskan Native

b. Asian or Pacific Islander

c. Black

d. White 
28. How would describe your ethnicity?

a. Hispanic origin

b. Non-Hispanic origin

29. Please describe where you live.

a. Farm or ranch

b. A town with a population under 10,000 or Rural Non-Farm

c. Town or city with a population of 10,000 to 50,000

d. Suburb or city with a population over 50,000

e. City with a population over 50,000

30. Are you currently a 4-H member?

a. Yes

b. No

31. Are you currently a FFA member?

a. Yes

b. No

32. How many years have you been a 4-H member?

33. How many years have you been an FFA member?

34. Have you ever attended a livestock ethics class or presentation?

a. Yes

b. No 
35. I exhibited the following livestock in 2008. (check all that apply)

\begin{tabular}{|c|c|c|c|c|}
\hline & $\begin{array}{c}\text { County } \\
\text { 4-H/FFA } \\
\text { Fair or } \\
\text { Exhibitions }\end{array}$ & $\begin{array}{c}\text { State } \\
\text { 4-H/FFA } \\
\text { Fair or } \\
\text { Exhibitions }\end{array}$ & $\begin{array}{c}\text { Breed } \\
\text { Association } \\
\text { Shows }\end{array}$ & $\begin{array}{l}\text { Other } \\
\text { Livestock } \\
\text { Exhibition } \\
\text { Shows }\end{array}$ \\
\hline \multicolumn{5}{|l|}{ Market steer } \\
\hline \multicolumn{5}{|l|}{ Feeder calves } \\
\hline \multicolumn{5}{|l|}{ Beef heifers } \\
\hline \multicolumn{5}{|l|}{ Other breeding beef cattle } \\
\hline \multicolumn{5}{|l|}{ Market lambs } \\
\hline \multicolumn{5}{|l|}{ Purebred lambs } \\
\hline \multicolumn{5}{|l|}{ Other breeding sheep } \\
\hline \multicolumn{5}{|l|}{ Market hogs } \\
\hline \multicolumn{5}{|l|}{ Purebred hogs } \\
\hline \multicolumn{5}{|l|}{ Other breeding swine } \\
\hline \multicolumn{5}{|l|}{ Dairy } \\
\hline \multicolumn{5}{|l|}{ Rabbits } \\
\hline \multicolumn{5}{|l|}{ Goats } \\
\hline \multicolumn{5}{|l|}{ Poultry } \\
\hline \multicolumn{5}{|l|}{ Horses } \\
\hline Other (please specify & & & & \\
\hline
\end{tabular}


36. What does the statement "livestock ethics" mean to you?

37. What other ethical concerns/issues not addressed by this survey would you like to comment on? 


\section{Comments:}

Thank you for taking the time to complete this questionnaire!!

If you have any questions regarding the questionnaire, please contact me at: sankrom@mix.wvu.edu 
APPENDIX J

Questionnaire: Parent Participants 


\section{Parents' Perceptions of Ethical Practices in Youth Livestock Shows}
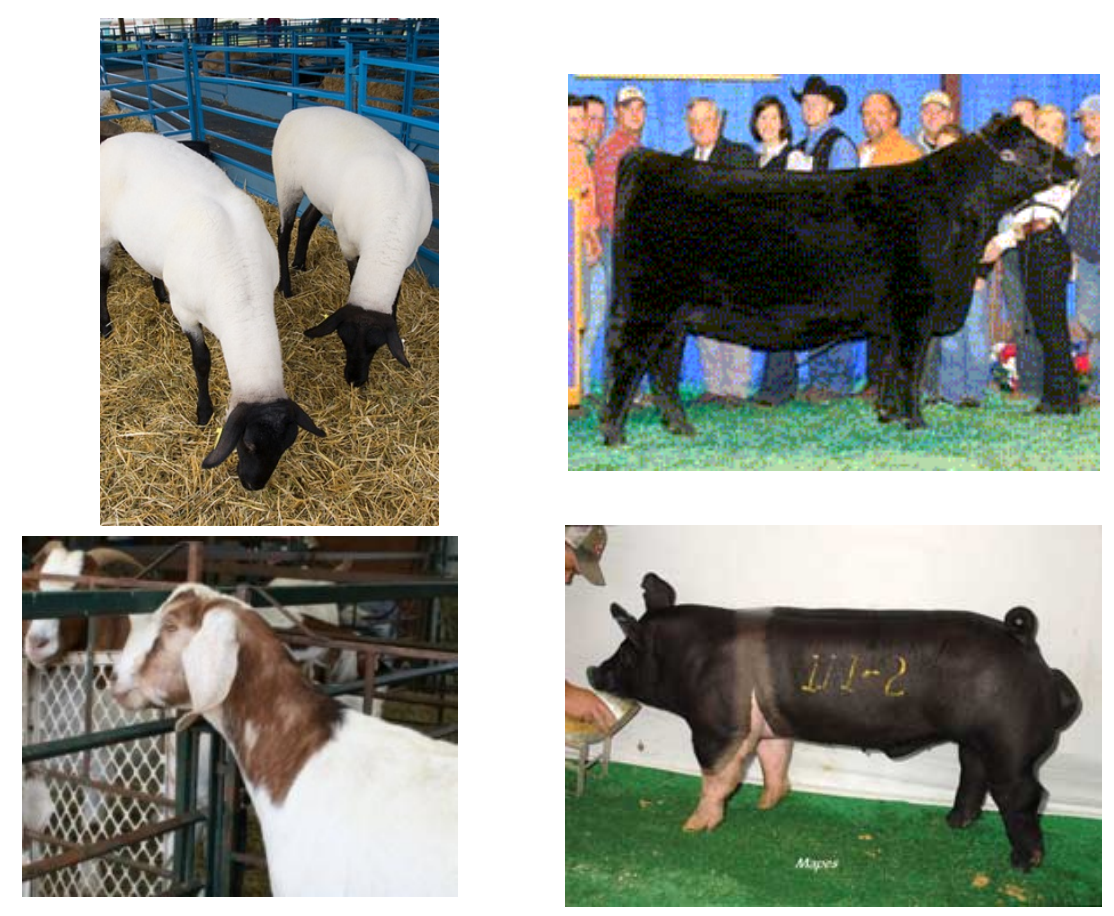

\section{Sharon J. Ankrom}

Graduate Student

Agricultural and Extension Education

Davis College of Agriculture, Forestry, and Consumer Sciences

West Virginia University

Morgantown, WV 26505 


\section{Parents' Perceptions of Ethical Practices in Youth Livestock Shows}

Instructions: Read each of the following statements and indicate your response by circling whether you perceive the practice is unethical, ethical, or you do not know. You should have only one response for each of the statements.

Example: Read the following statement. Assume you perceive that it is ethical for colleges to allow every applicant admission. Circle ethical for your answer.

\begin{tabular}{|c|c|c|}
\hline \multicolumn{3}{|c|}{ Example: } \\
\hline Statement & Response & \\
\hline $\begin{array}{l}\text { Public colleges should admit every student } \\
\text { who submits an application. }\end{array}$ & Unethical & Not Sure \\
\hline
\end{tabular}

\begin{tabular}{|c|c|c|c|}
\hline Statement & \multicolumn{3}{|c|}{ Response } \\
\hline $\begin{array}{l}\text { 1. Adults coaching youth from the } \\
\text { sidelines is: }\end{array}$ & Unethical & Ethical & Not Sure \\
\hline 2. Adults preparing animals for youth is: & Unethical & Ethical & Not Sure \\
\hline $\begin{array}{l}\text { 3. Adults questioning the livestock judge } \\
\text { is: }\end{array}$ & Unethical & Ethical & Not Sure \\
\hline $\begin{array}{l}\text { 4. Adults sharing preparation of animals } \\
\text { with the youth is: }\end{array}$ & Unethical & Ethical & Not Sure \\
\hline $\begin{array}{l}\text { 5. Animals cared for by someone other } \\
\text { than the exhibitor is: }\end{array}$ & Unethical & Ethical & Not Sure \\
\hline 6. Cutting lambs' tails too close is: & Unethical & Ethical & Not Sure \\
\hline $\begin{array}{l}\text { 7. Encouraging an animal to drink a great } \\
\text { deal of water is: }\end{array}$ & Unethical & Ethical & Not Sure \\
\hline $\begin{array}{l}\text { 8. Giving fluids (other than water) to an } \\
\text { animal is: }\end{array}$ & Unethical & Ethical & Not Sure \\
\hline
\end{tabular}




\begin{tabular}{|c|c|c|c|}
\hline Statement & \multicolumn{3}{|c|}{ Response } \\
\hline $\begin{array}{l}\text { 9. Grooming of animals by professionals } \\
\text { is: }\end{array}$ & Unethical & Ethical & Not Sure \\
\hline 10. Hitting uncooperative animals is: & Unethical & Ethical & Not Sure \\
\hline $\begin{array}{l}\text { 11. Injection of fluids under an animal's } \\
\text { skin is: }\end{array}$ & Unethical & Ethical & Not Sure \\
\hline $\begin{array}{l}\text { 12. Leaving lambs in trimming chutes for } \\
\text { extended periods of time is: }\end{array}$ & Unethical & Ethical & Not Sure \\
\hline $\begin{array}{l}\text { 13. Paying above market value for animals } \\
\text { is: }\end{array}$ & Unethical & Ethical & Not Sure \\
\hline $\begin{array}{l}\text { 14. Pulling a lamb's head where its feet } \\
\text { leave the ground is: }\end{array}$ & Unethical & Ethical & Not Sure \\
\hline 15. Pumping air under an animal's skin is: & Unethical & Ethical & Not Sure \\
\hline 16. Restrictive feeding of an animal is: & Unethical & Ethical & Not Sure \\
\hline 17. Running overweight animals is: & Unethical & Ethical & Not Sure \\
\hline $\begin{array}{l}\text { 18. Substituting an animal without notifying } \\
\text { the show committee is: }\end{array}$ & Unethical & Ethical & Not Sure \\
\hline 19. Talking to the judge(s) before a show is: & Unethical & Ethical & Not Sure \\
\hline $\begin{array}{l}\text { 20. Use of non-grooming products on an } \\
\text { animal is: }\end{array}$ & Unethical & Ethical & Not Sure \\
\hline $\begin{array}{l}\text { 21. Using mechanical equipment to teach } \\
\text { animals to lead is: }\end{array}$ & Unethical & Ethical & Not Sure \\
\hline 22. Using sedative type drugs on animals is: & Unethical & Ethical & Not Sure \\
\hline $\begin{array}{l}\text { 23. Youth questioning the livestock judge } \\
\text { is: }\end{array}$ & Unethical & Ethical & Not Sure \\
\hline
\end{tabular}


Instructions: Please read each question completely and place a check mark in front of the appropriate response or provide an answer where indicated.

24. What is your gender?

a. Male

b. Female

25. What is your age?

a. $21-30$ years of age

b. $31-40$ years of age

c. $41-50$ years of age

d. $51-60$ years of age

e. 61 years of age or older

26. What is your home state?

a. Maryland

b. Ohio

c. Pennsylvania

d. Virginia

e. West Virginia

27. Which of the following best describes your race?

a. American Indian or Alaskan Native

b. Asian or Pacific Islander

c. Black

d. White 
28. How would describe your ethnicity?

a. Hispanic origin

b. Non-Hispanic origin

29. Please describe where you live.

a. Farm or ranch

b. A town with a population under 10,000 or Rural Non-Farm

c. Town or city with a population of 10,000 to 50,000

d. Suburb or city with a population over 50,000

e. City with a population over 50,000

30. As a youth, were you currently a 4-H member?

a. Yes

b. No

31. As a youth, were you currently a FFA member?

a. Yes

b. No

32. How many years were you a 4-H member?

33. How many years were you a FFA member?

34. Have you ever attended a livestock ethics class or presentation?

a. Yes

b. No 
35. My son(s)/daughter(s) exhibited the following livestock in 2008. (check all that apply)

\begin{tabular}{|c|c|c|c|c|}
\hline & $\begin{array}{c}\text { County } \\
\text { 4-H/FFA } \\
\text { Fair or } \\
\text { Exhibitions }\end{array}$ & $\begin{array}{c}\text { State } \\
\text { 4-H/FFA } \\
\text { Fair or } \\
\text { Exhibitions }\end{array}$ & $\begin{array}{c}\text { Breed } \\
\text { Association } \\
\text { Shows }\end{array}$ & $\begin{array}{c}\text { Other } \\
\text { Livestock } \\
\text { Exhibition } \\
\text { Shows }\end{array}$ \\
\hline Market steer & & & & \\
\hline Feeder calves & & & & \\
\hline Beef heifers & & & & \\
\hline Other breeding beef cattle & & & & \\
\hline Market lambs & & & & \\
\hline Purebred lambs & & & & \\
\hline Other breeding sheep & & & & \\
\hline Market hogs & & & & \\
\hline Purebred hogs & & & & \\
\hline Other breeding swine & & & & \\
\hline Dairy & & & & \\
\hline Rabbits & & & & \\
\hline Goats & & & & \\
\hline Poultry & & & & \\
\hline Horses & & & & \\
\hline Other (please specify & & & & \\
\hline & & & & \\
\hline & & & & \\
\hline & & & & \\
\hline & & & & \\
\hline & & & & \\
\hline & & & & \\
\hline
\end{tabular}


36. What does the statement "livestock ethics" mean to you?

37. What other ethical concerns/issues were not addressed by the questions in this survey? 


\section{Comments:}

Thank you for taking the time to complete this questionnaire!!

If you have any questions regarding the questionnaire, please contact me at: sankrom@mix.wvu.edu 


\section{APPENDIX K}

Consent Form for Youth Participants 


\title{
WWestliginiauniversity. \\ Office of Research Compliance
}

\section{PARENTAL OR GUARDIAN CONSENT AND INFORMATION FORM}

\author{
OMR-Parental Consent
}

\author{
Principal Investigator: Boone, Harry \\ Department: $\quad$ AGRICULTURE \& FORESTRY - Resource Management \\ Tracking Number: $\quad \mathrm{H}-21654$
}

Study Title:

Perceptions of Ethical Practices in Youth Livestock Shows

Co-Investigator(s):

Ankrom, Sharon

Sponsor

\section{Contact Persons}

If you have any questions, concerns, or complaints about this research,you can contact Dr. Harry Boone at 304/293-4832 ext. 4481 or email himat hnboone@wvu.edu.

For information regarding your rights as a research subject, you may contact the Office of Research Compliance at 304/293-7073

\section{Introduction}

You have been asked to allow your child to participate in this study, which has been explained to you and your child by Sharon Ankrom and Dr. Harry Boone in the cover letter. This study is being conducted by Sharon Ankrom and Dr. Harry Boone in the Department of Agricultural and Extension education at West Virginia University. This research is being conducted to fulfill the requirements for a masters thesis in the Department of Agricultural and Extension Education at West Virginia University, under the supervision of Harry N. Boone, Jr., Ph.D.

\begin{tabular}{lll}
\hline Tracking \#: & $\mathrm{H}-21654$ & Page 1 of 4 \\
Approved On: & $04 / 27 / 2009$ & \\
Valid Through: & $04 / 26 / 2010$ & \\
Last Amended: & $\mathrm{N} / \mathrm{A}$ &
\end{tabular}

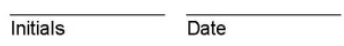


Tracking \#: $\quad \mathrm{H}-21654$

Purposes of the Study

The purpose of this study is to determine the perceptions of 4- $\mathrm{H}$ youth of the ethical nature (right verses wrong) of practices used in livestock shows. WVU expects to enroll approximately 200 subjects to participate in this study.

\section{Description of Procedures}

This study involves a series of questions on the ethical nature (right verses wrong) of practices used in showing livestock and will take less than fifteen minutes for your child to complete. Your child does not have to answer all the questions. You will have the opportunity to see the questionnaire before signing this consent form.

Approximately 200 subjects are expected to participate in this study.

\section{Risks and Discomforts}

There are no known or expected risks to your child from participating in this study, except for the mild frustration associated with answering the questions.

\section{Alternatives}

Your child does not have to participate in this study.

\section{Benefits}

The results of the study will be used to develop training materials on approved practices in showing livestock.

\section{Financial Considerations}

No payments will be made for participating in the study.

\section{Confidentiality}

Any information about your child that is obtained as a result of participation in this research will be kept as confidential as legally possible. Your child's research records and test results, just like hospital records, may be subpoenaed by court order or may be inspected by federal

Tracking \#:

Approved On:

Valid Through:

Last Amended:
Page 2 of 4

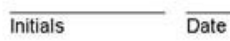


Tracking \#: $\quad \mathrm{H}-21654$

regulatory authorities without your additional consent. In addition, there are certain instances where the researcher is legally required to give information to the appropriate authorities. These would include mandatory reporting of infectious diseases, mandatory reporting of information about behavior that is imminently dangerous to your child such as suicide, child abuse, etc. In any publications that result from this research, neither your child's name nor any information from which your child might be identified will be published without your consent.

\section{Voluntary Participation}

Participation in this study is voluntary. You or your child may refuse to participate in this study. You or your child may withdraw from this study at any time. Refusal to participate or withdrawal will not affect your child's 4- $\mathrm{H}$ membership status and privileges, and will involve no penalty to you or your child. In the event new information becomes available that may affect your willingness to allow your child to participate in this study, this information will be given to you so that you can make an informed decision about whether or not to continue your child's participation. You have been given the opportunity to ask questions about the research, and have received answers concerning areas you did not understand.

A second copy of this Consent Form has been included in this mailing. Please keep this copy for your records.

Tracking \#:

Approved On:

Valid Through:

Last Amended:
H-21654

$04 / 27 / 2009$

$04 / 26 / 2010$

N/A
Page 3 of 4

Initials 
Upon signing this form, you will receive a copy.

I willingly consent to allow my child to participate in this research.

Signature of Parent or Guardian

Printed Name

Date

Time

The parent/guardian has had the opportunity to have questions addressed. The parent/guardian willingly agrees to allow his/her child to be in the study.

Signature of Investigator or

Printed Name

Date

Time

Co-Investigator

Tracking \#:

Approved On:

Valid Through:

Last Amended:
H-21654

$04 / 27 / 2009$

$04 / 26 / 2010$

N/A
Page 4 of 4

Initials

Date 


\section{APPENDIX L}

Assent Form for Youth Participants 


\title{
WWestVirginiaUniversity. \\ Office of Research Compliance
}

\section{ASSENT FORM}

\author{
OMR-Assent
}

Principal Investigator: Boone, Harry

Department: $\quad$ AGRICULTURE \& FORESTRY - Resource Management Tracking Number: $\quad \mathrm{H}-21654$

Study Title:

Perceptions of Ethical Practices in Youth Livestock Shows

Co-Investigator(s):

Ankrom, Sharon

Sponsor

\section{Contact Persons}

If you have any questions, concerns, or complaints about this research, you can contact Dr. Harry Boone at 304/293-4832 ext. 4481 or email him at hnboone@wvu.edu.

For information regarding your rights as a research subject, you may contact the Office of Research Compliance at 304/293-7073.

Introduction

You have been asked to be in this research study, which has been explained to you in the cover letter.

Purposes of the Study

The purpose of this study is to determine the perceptions of $4-\mathrm{H}$ youth of the ethical nature (right verses wrong) of practices used in livestock shows.

\begin{tabular}{lll}
\hline Tracking \#: & $\mathrm{H}-21654$ & Page 1 of 3 \\
Approved On: & $04 / 27 / 2009$ & \\
Valid Through: & $04 / 26 / 2010$ & \\
Last Amended: & N/A &
\end{tabular}

$\overline{\text { Initials }} \overline{\text { Date }}$ 
Tracking \#: $\quad H-21654$

\section{Description of Procedures}

You will be asked to complete a series of questions on your perceptions of the ethical nature (right verses wrong) of practices used in showing livestock. It will take less than fifteen minutes to complete the questionnaire. You do not have to answer all of the questions.

\section{Discomforts}

There are no foreseeable discomforts associated with participation in the study.

\section{Benefits}

The results of the study will be used to develop training materials on approved practices in showing livestock.

\section{Confidentiality}

We promise that anything we learn about you in this study will be kept as secret as possible.

\section{Voluntary Participation}

You do not have to do this. No one will be mad at you if you refuse to do this or if you decide to quit. Your 4- $\mathrm{H}$ membership status and privileges will not be affected if you do not complete the form. You have been allowed to ask questions about the research, and all of your questions were answered.

$\begin{array}{lll}\text { Tracking \#: } & \mathrm{H}-21654 & \text { Page } 2 \text { of } 3 \\ \text { Approved On: } & 04 / 27 / 2009 & \\ \text { Valid Through: } & 04 / 26 / 2010 & \\ \text { Last Amended: } & \text { N/A } & \end{array}$

$\overline{\text { Initials }} \overline{\text { Date }}$


I willingly agree to be in this research.

Signature of Subject

The child has had the opportunity to have questions addressed. The child willingly agrees to be in the study.

Signature of Investigator or

Printed Name

Date

Time

Co-Investigator

$\begin{array}{ll}\text { Tracking \#: } & \mathrm{H}-21654 \\ \text { Approved On: } & 04 / 27 / 2009 \\ \text { Valid Through: } & 04 / 26 / 2010\end{array}$

Valid Through: $\quad 04 / 26 / 201$

Last Amended: N/A 


\section{APPENDIX M}

Consent Form for Youth Participants Over 18 Years of Age 


\section{WWestVirginiaUniversity. \\ Office of Research Compliance \\ CONSENT AND INFORMATION FORM}

OMR Consent 18 years or older

Principal Investigator: Boone, Harry

Department: $\quad$ AGRICULTURE \& FORESTRY - Resource Management Tracking Number: $\mathrm{H}-21654$

Study Title:

Perceptions of Ethical Practices in Youth Livestock Shows

Co-Investigator(s):

Ankrom, Sharon,

Sponsor

\section{Contact Persons}

If you have any questions, concerns, or complaints about this research, you can contact Dr. Harry Boone at (304) $293-4832$ ext. 4481 or email him at hnboo ne@wvu.edu.

For information regarding your rights as a research subject, you may contact the Office of Research Compliance at 304/293-7073.

\section{Introduction}

You have been asked to participate in this study, which has been explained to you by Sharon Ankrom and Dr. Harry Boone in the cover letter. This study is being conducted by Sharon Ankrom and Dr. Harry Boone in the Department of Agricultural and Extension Education at West Virginia University. This research is being conducted to fulfill the requirements for a master's thesis in the Department of Agricultural and Extension Education at West Virginia University, under the supervision of Harry N. Boone, Jr., Ph.D.

\begin{tabular}{lll}
\hline Tracking \#: & $\mathrm{H}-21654$ & Page 1 of 4 \\
Approved On: & $04 / 27 / 2009$ & \\
Valid Through: & $04 / 26 / 2010$ & \\
Last Amended: & $\mathrm{N} / \mathrm{A}$ &
\end{tabular}

$\overline{\text { Initials }} \overline{\text { Date }}$


Tracking \#: $\quad \mathrm{H}-21654$

\section{Purposes of the Study}

The purpose of this study is to determine the perceptions of $4-\mathrm{H}$ youth of the ethical nature (right versus wrong) of practices used in livestock shows. WVU expects to enroll approximately 200 subjects to participate in this study.

\section{Description of Procedures}

This study involves a series of questions on the ethical nature (right verses wrong) of practices used in showing livestock and will take less than fifteen minutes to complete. You do not have to answer all the questions. You will have the opportunity to see the questionnaire before signing this consent form. Approx imately 200 subjects are expected to participate in this study.

\section{Risks and Discomforts}

There are no known or expected risks from participating in this study, except for the mild frustration associated with answering the questions.

\section{Alternatives}

You do not have to participate in this study.

\section{Benefits}

The results of the study will be used to develop training materials on approved practices in showing livestock.

\section{Financial Considerations}

No payments will made for participating in the study.

\section{Confidentiality}

Any information about you that is obtained as a result of your participation in this research will be kept as confidential as legally possible. Your research records and test results, just like hospital records, may be subpoenaed by court order or may be inspected by federal regulatory

Tracking \#

Approved On:

$\mathrm{H}-21654$

04/27/2009

Valid Through: $\quad 04 / 26 / 2010$

Last Amended: N/A
Page 2 of 4

$\overline{\text { Initials }} \overline{\text { Date }}$ 
Tracking \#: $\quad H-21654$

authorities without your additional consent. In addition, there are certain instances where the researcher is legally required to give information to the appropriate authorities. These would include mandatory reporting of infectious diseases, mandatory reporting of information about behavior that is imminently dangerous to you or to others, such as suicide, child abuse, etc. In any publications that result from this research, neither your name nor any information from which you might be identified will be published without your consent.

\section{Voluntary Participation}

Participation in this study is voluntary. You are free to withdraw your consent to participate in this study at any time. Refusal to participate or withdrawal will not affect your $4-\mathrm{H}$ membership status and privileges and will involve no penalty to you. In the event new information becomes available that may affect your willingness to participate in this study, this information will be given to you so that you can make an informed decision about whether or not to continue your participation. You have been given the opportunity to ask questions about the research, and you have received answers concerning areas you did not understand.

\begin{tabular}{lll}
\hline Tracking \#: & $\mathrm{H}-21654$ & Page 3 of 4 \\
Approved On: & $04 / 27 / 2009$ & \\
Valid Through: & $04 / 26 / 2010$ & \\
Last Amended: & N/A &
\end{tabular}


Upon signing this form, you will receive a copy.

I willingly consent to participate in this research.

$\begin{array}{llll}\begin{array}{l}\text { Signature of Subject or } \\ \text { Subjects Legal Representative }\end{array} & \text { Date } & \text { Time }\end{array}$

The participant has had the opportunity to have questions addressed. The participant willingly agrees to be in the study.

Signature of Investigator or

Printed Name

Date

Time

Co-Investigator

$\begin{array}{lll}\text { Tracking H: } & \mathrm{H}-21654 & \text { Page } 4 \text { of } 4 \\ \text { Approved On: } & 04 / 27 / 2009 & \\ \text { Valid Through: } & 04 / 26 / 2010 & \\ \text { Last Amended: } & \text { N/A } & \end{array}$

Initials $\overline{\text { Date }}$

Last Amended: N/A 


\section{APPENDIX N}

Checklist for Youth Participants 


\section{Instruction Sheet}

\section{4-H and FFA Youth}

1. Read the 4-H/FFA Livestock Show Exhibitor cover letter

2. Give your parents the 4-H/FFA Livestock Show Exhibitor Parent cover letter and CONSENT forms (pink forms)

3. Get permission from your parents to participate in the study

4. Complete the ASSENT form (yellow form) (initial page 1 and sign page 2)

5. Complete the questionnaire

6. Collect the questionnaire, ASSENT (yellow), and CONSENT (pink) forms

7. Place the three items in the reply envelope and drop in the mail (no postage is needed)

\section{Parents of 4-H and FFA Youth}

1. Read the 4-H/FFA Livestock Show Exhibitor Parent cover letter

2. Give your son/daughter permission to complete the questionnaire

3. Sign one copy of the CONSENT form (pink form) (initial page 1 and sign page 2)

4. Return one signed copy of the CONSENT form (pink form) to Sharon Ankrom

5. Keep a copy of the CONSENT form (pink form) for your records.

6. Assist your son/daughter with returning the questionnaire, ASSENT (yellow), and CONSENT (pink) forms in the reply envelope provided (no postage is needed)

Thank you very much for allowing your son/daughter to participate in this research study. 
APPENDIX O

Open-ended Responses: What Does Livestock Ethics Mean to Respondents? 
What does livestock ethics mean to you?

- "Livestock ethics" means fairness to me.

- A project is to be a learning experience that will help the member mature, take leadership, be competitive, and to understand the judge is the person in charge.

- Additionally, youth conducting themselves in an ethical manner while working with animals and people.

- Also without the use of drugs or other products.

- Also, livestock ethics means proper handling and keeping animals

- Also, members treating each other with respect.

- Also, obeying the ethics helps prevent any dangers/harm than can occur to the livestock.

- And not cheating

- And that they be used and shown in the way they were intended to.

- Animals should not be, chemically or grooming wise, made to look like they are prime animals.

- Animals trained and raised by someone other than 4-H member should not be allowed.

- And treat your animals the best you can

- Approved practices.

- Being fair and cooperative in and out of the show ring!

- By obeying the ethical laws, all exhibitors can prepare and show their animals in the same manner which makes everyone fair.

- Caring for animals, proper feed water etc.

- Conducting yourself and your business in a manner that is fair for all and humane for the animals.

- Do not cheat.

- Doing the right thing even if you know you will loose. 
- Doing the right thing with your livestock.

- Doing things the right way.

- Doing what's best for the animal's welfare and what is fair to other exhibitors.

- Doings what's right for the animal.

- Each state does things different even though it's a federal program.

- Enjoy the experience of raising an animal not doing "anything" to win a prize/

- Every livestock exhibitor and animal should be judged fairly.

- Examples: no drugs such as sedatives or muscle developers, no hair dye

- Exhibiting good sportsmanship.

- Feeding and caring for animals properly

- Follow the rules

- Following all commonsense-written rules and regulations.

- Following the rules and regulations so it will be fair for all of the exhibitors.

- Following the rules.

- Following the rules of the organization.

- For example having a professional fit your steer doesn't give you an advantage in the show ring, but talking to a judge before a show could cause an animal to get higher place than it should.

- Going mechanical, and using anything the animal doesn't provide is unethical

- Good sportsmanship and the judge is always right

- Good sportsmanship of exhibitors.

- Guidelines/acceptable practices

- Honesty, integrity, and fairness

- How you should treat an animal.

- How you treat your animal. 
- Human treatment of livestock.

- I myself acting in what I believe to be right.

- It also means keeping a level playing field in the show ring.

- It means "code of conduct" or set of rules that a livestock participant should/is expected to follow

- It means "doing the right thing" for the member and the animal.

- It means a lot to me.

- It means how you take care of your animals.

- Know the right preparation and when to feed prior to show.

- Livestock dealers should not overcharge 4-H members for their projects.

- Livestock ethics is how the animal is treated, whether it's good or bad.

- Livestock ethics is the way an exhibitor and their family should act towards the livestock being shown.

- Livestock ethics mean correct treatment of animals.

- Livestock ethics means being right to an animal

- Livestock ethics means taking every precaution to keep animals healthy and produce quality meat for buyers.

- Livestock ethics means to me the growing and showing of animal that is fair to all involved.

- Livestock ethics means treating an animal the way you would want to be treated

- Livestock ethics to me is the time, and fairness you put into your animal.

- Livestock ethics to means to me: Follow all rules judge fairly no kid should be give special treat because there parents have connection.

- Livestock ethics means treating animals in manner which is both safe for animal and exhibitor.

- More to competitive showing than feeding and coming into ring.

- Not cheating 
- Not letting the animal suffer, and not cheating by manually "making better" that is not naturally provided by the animal.99

- Not winning as the expense of the animal

- (State) now wants sheep, cattle and horses to have a rabies vaccine, but not market animals. How can the ram lambs I show for breeding be safe to eat after being vaccinated of the market animals don't need done?

- Parent as helper/guide no as doer

- People taking care of there animals and presenting them for show WITHOUT cheating!

- Preparing animals for exhibition in a humane way that does not harm or alter the food product that will eventually be harvested.

- Presenting yourself and your animal in a straight forward and honest manner.

- Proper care and responsibility for the animals the member has as projects.

- Proper treatment of animals-this shouldn't need explanation.

- Quality of keeping healthy animals without using drugs, or treating your animal with harm.

- Should be shown in their natural state with the exception of lamb, bulls and boar hogs.

- Showmanship and how you use morals in or around the show ring

- That an animal not be physically altered from its natural appearance.

- That livestock rules are not violated and the animals are treated correctly.

- The "right" way to care for animals.

- The ethics of raising livestock.

- The proper way of treating your animal before and after the show.

- The proper way to treat and care for your animals.

- The scrapie eradication program is wrong because the tests are different and most of the time the people in charge have different ways of dealing with it.

- The standards for livestock show. 
- The well being of the animal.

- Things should be fair and honest when it comes to the exhibitors and the livestock should be treated humanely.

- This is unsafe and market does not call for it.

- To be fair and truthful with everybody your competing

- To do right with your animal projects.

- To keep P.E.T.A from coming after us.

- To keep the animal and exhibitor safe, and healthy.

- To learn the basics of livestock such as taking care, knowing, keeping healthy and put hard work, care and love in the animal you raise.

- To me, livestock ethics is being able to get the most out of the animal you have raised. (Ex. Giving salt water to enlarge calf, having professional groom your calf, but still staying natural.)

- To see cows and calves honestly

- Treating an animal fairly while preparing for competitive competition.

- Treating animals in a humane fashion and show ring values and integrity in the way you present and treat your animals.

- Treating animals in a humane way.

- Treating animals in the same way that a person should be treated: in a healthy manner, in a manner that improves their quality.

- Treating it nice

- Treating of animals humanely and justly.

- Treating the animal in a fair way by all party's involved-exhibitors, parents, 4-H leader, 4-H agents, and FFA advisors!

- Treating the animal with respect.

- Unless it is done for animal health issues.

- Using common sense to make sure all kids have a level playing field. 
- What you can do to an animal that doesn't harm the animal in any way.

- What you should and should not do to an animal.

- What you should do or is okay to do with your animal.

- You should not be judged by your money status or name. 


\section{APPENDIX P}

Open-ended Responses: Other Ethical Areas That Should be Addressed 
Other Ethical Areas That Should be Addressed:

- 4-H and FFA should purchase hogs etc and allow kids to pick from the same lot.

- 4-H members "leasing" market lambs.

- A couple years ago the rule was of you could get a pencil under it that was pretty fair length.

- Adults doing the project for the child

- Adults having kids show their animals

- All around fair treatment of animals including living conditions.

- Animals should be raised with industry proven best management practices.

- Congratulating other showers in the ring when you win

- Extension Agents, with 4-H age children, speaking to judge prior to show.

- Feeding of water melon before weigh in to bring up weight.

- For example the one concerning talking to a judge as an adult.

- Grooming-we need more workshops across the state to inform and demonstrate to our 4-H and FFA members all "livestock ethics"!

- Hosing lambs with cold water right before class.

- I believe it would depend on the conversation subject and as a youth, talking to the judge afterward could be a good learning tool.

- I believe that some of the questions in this survey do not have a specific right or wrong answer.

- I do not believe in castrating market goats because it slows done their growth.

- I do not believe in dehorning goats for safety reasons.

- I some cases, I do believe outside fitting is ok.

- I think some of the questions were one-sided. 
- I think the tail rule on market lambs needs to be done away with.

- I think the way a 4-Hers animals is treated by the stockyards and people hauling the animals are very unethical.

- I think there should be a better way to make sure members can't show market goats that are over 1 year old and they should not show market goats over acceptable weights for market, which is between 60 and $90 \mathrm{lbs}$.

- I think there should be a dress code for the girls. Boys no hats.

- I think you hit all of the topics it is just people need to do the right thing.

- If too long it looks really bad.

- If too short the exhibitor would have worked hard all summer just to be disappointed.

- In sports, there are "coaches".

- Leaders and adults should be there to show, assist and help a member to learn to be able to do the fitting for himself.

- Leaving show ring before judge is done speaking about other members' animals.

- Measuring lambs tails to the right length is difficult.

- Members using animals that are not their own.

- None of them

- Not any at this present time.

- One person gets treated differently then another person How can putting livestock to death to test them and it comes back negative be ethical?

- Parents helping their children until they are able to do it on their own is ethical.

- Parents interfering with showing and persuading the judges.

- Proper fitting techniques

- Running up bidding during auctions. 
- Selling them and not sharing the sell money with the kids

- Should not pay extreme prices for project animals.

- Some of the questions are somewhat vague.

- Someone else showing your animal that you worked on, just because you weren't good enough is unethical.

- Sometimes it's a learning experience for the youth to question and find out what they could do to improve.

- Spraying lambs with alcohol.

- Switching birthdates of breeding animals-very unethical!

- Tail docks are a big issue in ethics.

- The animal not being the proper age.

- The answer depends greatly on the circumstances surrounding the situation and the age of the child and temperament of the animal.

- The cattle I believe are still here to do there part and it is definitely the animal I'm sticking to in the future.

- The [County] 4-H livestock shows have went down hill since I was a 4-H member.

- The kids are not interested in 4-H, or even going to camp. I think my son would enjoy come more if they had a class on showmanship for your calf. Grooming your animal.

- The regulation now is entirely too long.

- There is one Grand Champion per event.

- To keep a positive attitude

- Too much emphasis on winning, mainly due to money received for champion, etc.

- We are exhibiting theses projects for youths to learn the proper techniques.

- We work hard and take care of our animals and they beat them around and the people get a bad product that they think is from us. 
- Wealthy farmers paying above market value is unfair to those of us who don't have the opportunity to do what we love and be competitive.

- Where else to learn but from professionals.

- Why is showing projects different?

- Winning is fun, but it is not the ultimate goad.

- You questioned youth questioning judge-I feel a youth should question a judge after a show if they have questions about comments.

- Youth exhibitors not working with their animals until seeing them at the show. 


\section{APPENDIX Q}

Other Comments 


\section{Other Comments:}

- \#19 It's ethical as long as you aren't trying to influence the judge's future decisions.

- \#3 and \#23 Its ok to ask a judge how you can do better or to ask information.

- \#7-One may encourage an animal to drink but it will only drink what it wants (you can lead a horse to water but you can't make it drink) however, forcing water into an animal by means of a stomach tube to meet a minimum weight requirement is certainly unethical.

- $4-\mathrm{H}$ is a family activity.

- A number of your questions on ethics are too broad and could be interpreted incorrectly.

- Almost every state besides [state] doesn't have a tail rule.

- Also they say it's because of prolapsing.

- Also this survey was very well written

- Although some of the practices are done they aren't really "unethical" just opinion.

- As a 4-H leader for the past 25 years and a 4-H member since forever I have watch times change and creative ways develop to try and get around our "livestock ethics" which are very wrong.

- Asking a judge why they placed an animal where they did (in a good sportsmanship manner) is ethical.

- But eliminating this rule would be easier on the youth and the producers.

- But these are show lambs for market and it looks better and won't cause disappointment and trouble.

- Feel free too contact me in the future if you need more help.

- For example: what is "too close" to dock a lambs tail

- Glad too help!

- Good luck! (my wife is doing doctoral research, too!)

- Good luck. 
- Good survey!

- Half of the leaders just turned their head because they didn't see anything wrong with it.

- Having the tail rule has done nothing to help the lamb industry.

- How a person could present the animal better.

- I am happy to say the other half was quite upset.

- I can see if it's a ewe for breeding the tail could be not as short.

- I do not agree with [state]'s tail dock rules. We raise our own sheep and have had to deal with animal health issues when the lamb's tail is $6 \mathrm{ft}$ long, fly stick and maggots from wet manure staying on the tail.

- I feel sometimes that the whole "ethical" situation gets taken too far.

- I felt some of your questions were too vague.

- I have been a 4-H leader in swine and beef for the last 6 yrs.

- I have shown sheep all of my life (on the national level).

- I hope to see all our youth learn the fair and ethically correct ways to treat each other and the animals.

- I hope you get good response.

- I hope your research goes well and you are able to help make a difference with our youth-our future!

- I know I have tried and will continue to encourage and demonstrate ethical ways to all my 4-Her's!

- I think that encouraging your animals to drink more should be more defined.

- It is ok for adults to assist in grooming up to age 14 unless show specifies otherwise.

- It's unethical to question the judge's decision.

- I've had lambs with legal tail length that still have prolapsed.

- most questions are too broad to answer ethical/unethical 
- Non farm youth should have the opportunity to have an animal housed on another property and show the animal if they in an effort to visit farm and care for animal.

- Not all your questions can be answered by the words ethical or unethical.

- Our local fair [city] has always been such an ethical fair when it came to the 4$\mathrm{H}$ and FFA livestock projects.

- Our surrounding states do not have this rule so this has really hurt our income; we have lost our out-of-state buyers. Relating to tail docking

- Parents should help their children.

- Questions \#6 infers that "too close" is unethical.

- Some of the questions are kind of controversial so I answered with that in mind.

- Some of the questions are two sided.

- Some of the questions weren't worded right.

- Some of your questions are too vague.

- Specific situations of the general questions would change answer on many of the questions.

- Thank you

- Thank you for sending this survey.

- The state fair is not a state event but a [County] Fair.

- There is nothing wrong with exercising an animal, however running an animal to the point of exhaustion or starving in an attempt to meet a maximum weight requirement is another matter.

- These animals are for market and it's not going to matter once they've been butchered. Relating to tail docking

- These kids strike their animals, withhold feed and water, hose their lambs off before entering their class and leave the ring before the judge is done talking.

- This rule has also hurt our market; we can not sell club lambs and breeding sheep out of state because the tails are not short enough.

- Until two years ago when a group of kids "coached" by a man that teaches them 
to do anything to win started attending our fair.

- We are a 4-H family that has been involved for 12 years.

- Weren't really "ethical" or "unethical".

- We've had a lamb with a long tail prolapse and other people have too.

- What concerned me was the divide that those unethical treatments had on our leaders.

- What is a "great deal" of water

- What is an "extended period" for having a lamb on a trimming stand-you actually say chute-lambs are not usually in a chute.

- When talking to or questioning a judge I think it to be ethical to do so as a learning tool for what a judge is looking for. 
VITA

Sharon Jean Ankrom

June 2001

August-May 2002

May-September 2004

January - May 2006

May 2006

August 2009
Graduated-Butler Senior High School Butler, PA 16001

Block and Bridle Secretary

West Virginia University

Morgantown, WV 26506

Research Assistant

ANPH 424 Physiology of Reproduction West Virginia University

Morgantown, WV 26506

Teaching Assistant ANPH 356 Small Ruminant Production West Virginia University Morgantown, WV 26506

Bachelor of Science in Agriculture Animal and Veterinary Science West Virginia University Morgantown, WV 26506

Master of Science Agricultural and Extension Education West Virginia University Morgantown, WV 26506

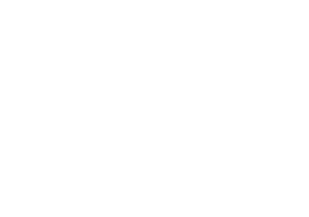

